\title{
Fuel accumulation in a high-frequency boreal wildfire regime: from wetland to upland
}

\begin{tabular}{|r|l|}
\hline Journal: & Canadian Journal of Forest Research \\
\hline Manuscript ID & Cjfr-2016-0475.R2 \\
\hline Danuscript Type: & Article \\
\hline Complete List of Authors: & $\begin{array}{l}\text { Thompson, Dan; Natural Resources Canada, Canadian Forest Service } \\
\text { Parisient, Marc-Andre; Natural Resources Canada, Canadian Forest Service } \\
\text { Morin, Jean; Parks Canada Agency } \\
\text { Millard, Koreen; Carleton University, Department of Geography and } \\
\text { Environmental Studies } \\
\text { Larsen, Chris; The State University of New York } \\
\text { Simpson, Brian; Natural Resources Canada, Canadian Forest Service }\end{array}$ \\
\hline Keyword: & boreal, wildfire, wetlands, fuels, vegetation structure \\
\hline $\begin{array}{r}\text { Is the invited manuscript for } \\
\text { consideration in a Special } \\
\text { Issue? : }\end{array}$ & N/A \\
\hline &
\end{tabular}


Thompson et al. Wildfire fuel loading in boreal wetlands and uplands

Fuel accumulation in a high-frequency boreal wildfire regime: from wetland to upland

2

D.K. Thompson ${ }^{1 *}$, M.A. Parisien ${ }^{1}$, J. Morin ${ }^{2}$, K. Millard ${ }^{3}$, C.P.S. Larsen ${ }^{4}$, B.N. Simpson ${ }^{1}$

4

${ }^{1}$ Natural Resources Canada, Canadian Forest Service, Northern Forestry Centre, Edmonton, Alberta,

6 Canada

${ }^{2}$ Parks Canada Agency, Wood Buffalo National Park, Fort Smith, Northwest Territories, Canada

$8{ }^{3}$ Carleton University, Department of Geography, Ottawa, Ontario, Canada

${ }^{4}$ Department of Geography, University at Buffalo, State University of New York, Amherst, New York, 10 14261, USA.

* Corresponding author: daniel.thompson@canada.ca; 1-780-435-7257 
Thompson et al. Wildfire fuel loading in boreal wetlands and uplands

\section{Abstract}

14 Although it is increasingly accepted that young (e.g., $\leq 30$ years) stands originating from wildfire are considerably less flammable than older stands in the boreal forest of North America, the role of fuel availability and structure in this phenomenon has not been thoroughly investigated. As a regional study in a high-frequency fire regime, detailed wildfire fuel loading and structure was measured in 66 sites

18 including both wetlands and uplands in the Boreal Plains landscape of Wood Buffalo National Park, in northwestern Canada. Overall, a significant increase in total flammable biomass occurred in upland

20 sites after 97 years but this increase was not consistently observed in wetlands, except where there was dense tree cover. Fuel accumulation was highly moderated by canopy fuels, as surface fuels were

22 relatively constant across differing site types and time since fire, averaging $0.4 \mathrm{~kg} \mathrm{~m}^{-2}$. Significant but gradual canopy fuel accumulation was observed in moist conifer upland forests dominated by mature

24 black spruce (Picea mariana) or white spruce (Picea glauca) over 100 years since fire. Outside of these mature moist conifer uplands, there was no difference in total fuel loading between other upland forest 26 and across the gradient of treed to open wetlands.

\section{1. Introduction}

Paleoecological reconstructions from tree rings (Wallenius et al. 2011) and charcoal and pollen (Larsen and MacDonald 1998) in boreal western Canada indicate a historic fire return interval that can be as short as 50-100 years, on average. Given that young stands (e.g., $\leq 20$ years postfire) may act as a barrier to fire spread in the boreal forest (Niklasson and Granström 2000; Bernier et al. 2016), it is in the most fire-prone parts of the boreal forest — that is, those with the greatest proportion of young 34 stands - that fire activity is likely to be the most limited by the lack of flammable biomass (Héon et al. 2014). Age-dependent thresholds such as the minimum canopy bulk density required to carry crown 
Thompson et al. Wildfire fuel loading in boreal wetlands and uplands

36 fire can play an important part in changing the flammability of a forest (Van Wagner 1977; Cruz et al. 2005), but how these important canopy structure characteristics change with time since fire in the boreal is poorly understood. Although empirical evidence from the Eurasian (Schimel and Granström 1997) and eastern North American boreal forest (Terrier et al. 2016) point to a general increase in

biomass following fire, the rates and patterns by which stands become more flammable is only partially understood in the boreal plains of western Canada, a vast area of intermixed upland forests and wetland 42 complexes.

Another open question is that of the flammability of boreal wetlands, which may cover a large (and even dominant) proportion of boreal landscapes and do indeed burn during periods of severe drought (Turetsky et al. 2004). The importance of flammable biomass accumulation has been mainly documented in upland forest (e.g. Bessie and Johnson 1995; Schimmel and Granström 1997). Whereas fuel accumulation on uplands is largely dependent of tree growth (Lavoie et al. 2010), this is not necessarily the case in boreal lowlands. The boreal forest of western Canada incorporates a wetness gradient from sedge-dominated (hydric) and treed wetlands to dry (xeric) upland forest (Raup 1935).

With wetlands covering approximately $25 \%$ of the boreal forest of western Canada (Tarnocai et al. 2011), knowledge of fire spread across the entire range of flammable ecosystems is essential to understanding landscape-scale wildfire patterns. The contribution of wetlands to boreal burned area have been reported to be both positive (Turetsky et al. 2004) and negative (Hellberg et al. 2001; Erni et al. 2016). Recent studies have reported surface fuel and canopy fire consumption levels comparable to those of upland forests (Benscoter and Wieder 2003; Lukenbach et al. 2015). Recent examinations have documented the accumulation of wildfire fuels over time in forested bogs (Johnston et al. 2015), in paludified forests of the Abititi clay belt in Ontario and Quebec (Terrier et al. 2016), alongside 
Thompson et al. Wildfire fuel loading in boreal wetlands and uplands

60 detailed fuels inventories in more minerotrophic wetlands by Schiks et al. (2016). However, a systematic examination of fuel loading over time and along this moisture gradient from treeless

62 wetlands to upload forest in boreal Canada is lacking.

64 Here we present a dataset of 66 ground plots documenting wildfire fuel structure and composition across a gradient from wetlands to xeric uplands, and spanning a range of time since fire, in Wood

66 Buffalo National Park, located in the province of Alberta and the Northwest Territories in Canada. Specifically, this study has three objectives: (1) evaluate how fuel loading changes with time since fire;

68 (2) examine differences between wetlands and uplands up to 250 years since fire; and (3) compare fuel loading across wetness gradients and time since fire with those from the Canadian Fire Behaviour

70 Prediction (FBP) System. In contrast to prior studies (e.g. Schimmel and Granström, 1997; Johnston et al. 2015) that focused on a specific ecosystem (e.g. pine uplands or spruce wetlands), here we assessed

72 fuel loading and structure across the range of ecosystems present in a region. These results will help us understand the landscape-level disturbance dynamics of the area and thereby allow for refinements of

74 our predictions of future fire activity in the North American boreal forest.

\section{2. Materials and methods}

This study took place entirely within Wood Buffalo National Park, which covers 4.4 Mha along the

78 Alberta-Northwest Territories border and is the largest national park with a frequent wildfire regime in Canada. Burned area within the park varies widely, with 37 of the past 56 years recording less than 10

80000 ha, while burned area exceeded 100000 ha in eight years. The climate in the region is dry and continental, with a mean annual temperature of $-1.8^{\circ} \mathrm{C}$, annual precipitation of $353 \mathrm{~mm}$ (Environment 82 and Climate Change Canada 2015), and annual potential evaporation of approximately $300 \mathrm{~mm}$ (Hare 
Thompson et al. Wildfire fuel loading in boreal wetlands and uplands

1980). The area lies in the northernmost extent of the Boreal Plains ecozone (Ecological Stratification

84 Working Group 1996) and boreal mixedwood forest region (Downing and Pettapiece 2005). The park is primarily covered by expansive lacustrine and aeolian glacial sediments, with shallower soils in the

86 Caribou and Birch Mountain plateaus in the southern and western edges of the park (Fenton et al.

2013). Coarse-textured upland mineral soils are dominated by pine (Pinus banksiana) or aspen

88 (Populus tremuloides), with 40-45\% of the park area composed of wetlands (Tarnocai et al. 2011) that can be a mixture of tree, shrub, or graminoid-dominated with at least $40 \mathrm{~cm}$ of underlying peat.

90 Permafrost is classified as being only sporadic in the region (Heginbottom 1995) and isolated to small pockets in peatlands. Extensive floodplain grasslands exist in the Peace-Athabasca Delta nearby Lake

92 Claire, the largest body of water in the parks (Figure 1). These wetlands are generally non-peat forming, and have been considered a disjunct prairie grassland community comparable to those 1000

$94 \mathrm{~km}$ further south (Schwarz 1994).

96 Reconstructions of the fire regime in the area prior to modern suppression indicate a mean fire return interval of 69 years (Larsen and MacDonald 1998). Though wildfire suppression has been active to

98 some extent since the 1950s, managed wildfire has prevailed over full suppression, with large burned areas in 1981 (650 000 ha), and in 2015 (372 000 ha; Natural Resources Canada 2016). The fire-

100 carrying capacity in Wood Buffalo National Park is evidenced by recent landscape-scale fires from 2012-2015 that burned an average of 5\% of the area of the park per year (Natural Resources Canada

102 2016). The area of Wood Buffalo National Park was listed as being in a long-term abnormally dry period during the summer of 2012 and 2013, with more normal conditions in 2014 followed by severe 104 long-term drought in 2015 (North American Drought Monitor 2016). 
Thompson et al. Wildfire fuel loading in boreal wetlands and uplands

$106 \quad 2.1$ Site selection

A total of 66 ground plots covering a gradient of time since fire and the main vegetation types of the

108 study area were selected and sampled in this study between 2012 and 2015 (Figure 1). These four years, though variable in terms of growing-season weather, were not atypical. The sites were sampled,

110 from mid-June to mid-July of each year in order to minimize the effect of phenological changes. Given the remote nature of the area, site selection was limited to areas within $2 \mathrm{~km}$ of the two roads in the

112 park $(n=42)(c f$. Wallenius et al. 2011), except when there was a possibility for helicopter access $(n=$ 24), in which case we could sample more remote sites ( $c f$. Larsen 1997). Preliminary statistical

114 explorations showed that that our sample size was suitable to meet our main objectives; there was thus no further sampling beyond 2015.

The nature of site selection was inherently opportunistic in light of the accessibility constraints;

118 however, given the vastness of the park (4.5 Mha) it was possible to select and adequately sample a range of stand ages and predetermined stand types. Sixteen of 66 sites burned the year prior under

120 variable burn severity, with a median site time since fire of 42 years that mirrors the short fire cycle in the area. Although we aimed to have a suitable diversity of stand ages, some gaps are present in the

122 time since fire gradient due to periods of low regional fire activity or lack of access. A total of 32 sites were classified as wetlands ( 11 treed, 5 shrubby, and 16 open sedge). Of the wetlands, 5 were

124 classified as bogs, 17 as fens, and the remaining 10 as floodplain or marsh wetlands. The remaining upland sites consisted of the following ecosites in order of increasing moisture status: dry pine lichen,

126 pine mixedwood, aspen-dominated, and moisture upland conifer. It was not possible to obtain a perfectly balanced design among vegetation types because of the aforementioned accessibility 128 constraints; however, the sampled vegetation types approximate their proportion in the landscape. 
$130 \quad 2.2$ Field sampling

The design of the ground plot was modified from Lavoie et al. (2010). At each plot, a 40-m transect

132 was laid out with quadrats at 5-m spacing, with 8 quadrats per plot. Biomass sampling was carried out by stratum: overstory trees, understory trees, tall shrubs, low live vegetation $(<0.5 \mathrm{~m}$ in height), and

134 litter. Four overstory trees were measured for height and diameter at breast height (dbh) at each quadrat using the point-centre quadrant technique. For the two stands measured in 2015 , there was a

136 slight variation in the plot design where the quadrats were laid out in a grid at $7.5 \mathrm{~m}$ spacing rather than along a single transect, changing only the layout of the quadrats but no other methods. Trees less than

138 3-cm dbh were measured in 3-m fixed-radius plots until 30 trees were measured or two plots were completed, whichever came first. Four square clip plots $(30 \times 30 \mathrm{~cm})$ captured live shrubs less than 50

$140 \mathrm{~cm}$ in height, as well as all other live grasses, sedges, and herbaceous vegetation. Surface litter was collected as dead plant material above the duff horizon with no signs of fungal or other decomposition.

142 The ratio of the accumulation of live sedges and grasses to the litter accumulation was calculated as a proxy for the residence time of litter in these simple fuel beds where live vegetation and litter

144 intermingle; this comparison is not possible in forests due to the movement of litter from the canopy to the forest floor. If taller shrubs were present, a 4-m width belt plot was constructed along the length of 146 the transect, with individual shrub volume estimated. Cube samples of foliage bulk density were taken that incorporated foliage, as well as live and dead branch wood as a bulk sample (Ganteaume et al.

148 2013). Coarse woody debris was measured along one or two 25-m long plane-intercept transects using the size classes from McRae et al. (1979). Duff and peat depth and density was measured in the field,

150 but not included in the sum of flammable biomass as duff consumption is largely limited to the smouldering phase (Frandsen 1998). 
Thompson et al. Wildfire fuel loading in boreal wetlands and uplands

152

Stand age was determined from several lines of evidence. Where available, stand age was measured by

154 tree-ring analysis from a representative dominant tree. Fire scars were also used to date the last fire; when these were not present, we collected a disk from a dominant tree that established after the fire.

156 For the 36 sites within a mapped historical fire, the age corresponding to the Canadian National Fire Database (Natural Resources Canada 2016) was used. Stand age established from previous studies

158 (Larsen 1997) was also used if located nearby sample plots, and were used to date two sites. For the 18 sites without a known fire origin that also lacked a tree section, we used known age-height relations

160 from Cieszewski et al (1993), which should be considered no more accurate than \pm 10 years.

162 Sites were classified according to the Ecosites of Northern Alberta System (Beckingham and Archibald 1996), down to the ecosite level. This classification scheme adds more detail compared to

164 classification by dominant tree species, as it considers understory vegetation, topographic position, and the moisture status of the site. Drainage class (xeric to hydric) was also assigned for each site.

166 Ecosites were assigned descriptive names similar to the vegetation associations of Raup (1935). Grass and sedge floodplain sites within the Peace-Athabasca Delta did not conform to any ecosites within the

168 framework, and were accordingly assigned an ecosite equivalent to an open fen.

\section{$170 \quad 2.3$ Fuel loading}

Fuel loads were calculated based on fuels available for flaming combustion only, and excludes other

biomass not subject to flaming combustion such as large woody debris, duff, and peat (Johnston et al. 2015). Standing deciduous trees were not counted toward fuel load calculations, as boreal deciduous trees do not contribute towards flaming combustion following the FBP system, owing to the high 
Thompson et al. Wildfire fuel loading in boreal wetlands and uplands

moisture content and low surface area of the foliage. For trees larger than 3-cm dbh, foliar biomass was

176 estimated using allometric equations based on height and dbh from Lambert et al. (2005). The fraction of flammable branchwood ( $<1 \mathrm{~cm}$ diameter) was estimated using the relationships from Alexander et

178 al. (2004), which breaks down flammable vs total branchwood. For trees less than 3-cm dbh, allometric equations from Alexander et al. (2004) were used for both foliar and branch wood biomass,

180 as the equations from Lambert et al. (2005) do not apply to such small trees. Since only black spruce (Picea mariana) and jack pine (Pinus banksiana) species allometric equations were available from

182 Alexander et al. (2004), white spruce was assumed to follow the allometric equations of black spruce; deciduous understory trees (including larch (Larix laricina)) were measured but not added to the sum

184 of fuel loading at a site. Total flammable biomass from the 32 measured overstory trees at each site was prorated to per square metre using the stem density computed from the point centred quarter

186 method. Tall shrub canopy characteristics were added into the canopy fuel load calculation, but were excluded from canopy bulk density calculations.

\subsection{Statistical Methods}

190 To achieve enough replicates for each ecosite, some of the original ecosite classifications were merged for the purposes of statistical power. For each grouping of wildfire fuels (surface, canopy, and total) in

192 both wetlands and uplands, the presence of a stepwise increase in the fuel load vs time since fire relationship was determined using the cross-entropy approach of Priyadarshana and Sofronov (2015)

194 using a truncated (zero-bound) normal distribution in the breakpoints package in the $R$ software version 3.2.2 (R Core Team 2016). If two breakpoints were found, a likelihood ratio test was used to determine 196 if the two-breakpoint model significantly $(p<0.05)$ improved the model power, and a one breakpoint model was chosen if equally powerful as a two-breakpoint model. Any resultant breakpoints found 
Thompson et al. Wildfire fuel loading in boreal wetlands and uplands

198 were then tested for a difference in means using an ordinary t-test between age classes. Additionally, Spearman's correlations were used to determine if a monotonic linear change in fuel load over time was present. Ordinary one-way ANOVAs with fuel loading as the dependent variable were performed on untransformed data using the base stats package in $R$. Independent levels for the ANOVAs were the ecosite groups as well as age classes as determined by the breakpoints analysis above. Tukey's HSD post-hoc tests were used to determine which ecosite and drainage levels were significantly different in 204 mean fuel loading from other levels.

\section{3. Results}

\subsection{Fuel loading over time}

208 Total fuel load available for surface fires (the sum of litter, live, shrubs, woody debris $<1.0 \mathrm{~cm}$ and understory tree pools) averaged $0.42 \pm 0.03 \mathrm{~kg} \mathrm{~m}^{-2}$, and was not related to time since fire (Spearman's $\rho$ $210=0.04 ; p=0.69)$. No breakpoint in the surface fuel load data was found when wetlands and uplands are considered together.

The three upland sites where there was evidence of a surface fire less than 30 years prior (the 214 approximate age limit for the visual detection of prior surface fire) had a mean canopy fuel load of 0.92 $\mathrm{kg} \mathrm{m}^{-2}$, while 13 other sites with evidence of stand-replacing fire (as shown by no living trees 216 established before the previous fire) had an average canopy fuel load of $0.16 \mathrm{~kg} \mathrm{~m}^{-2}$ (Figure 2), though small and uneven sample sizes do not allow for a direct comparison of means. Crown fuel load overall 218 was related to time since fire using a Spearman's rank correlation test $(\rho=0.518 ; \mathrm{p}<0.001 ;$ Figure 2$)$. No stepwise changes in canopy fuel load were observed using the cross-entropy test across the 
Thompson et al. Wildfire fuel loading in boreal wetlands and uplands

220 combination of wetlands and uplands.

222 Across both wetlands and uplands there was a strong time since fire effect on fuel accumulation $(\rho=$ 498; $\mathrm{p}<0.001)$. Though the breakpoint analysis did not reveal any stepwise changes in total fuel

224 loading across both wetlands and uplands, distinct increases in wetland and upload total fuel loads were observed at approximately 95 and 97 years after fire, respectively (Table 1). Though it was not

226 detected by the breakpoint analysis, we observed that recent fires (those $<10$ years since fire) showed a lower mean total fuel loading of $0.36 \mathrm{~kg} \mathrm{~m}^{-2}$ compared to older stands at $1.34 \mathrm{~kg} \mathrm{~m}^{-2}\left(t_{59}=4.5 ; p<\right.$ $2280.001)$

$230 \quad 3.2$. Wetland and upland fuels

Across all ages, mean litter load did not vary between wetlands $\left(0.24 \pm 0.04 \mathrm{~kg} \mathrm{~m}^{-2}\right.$; mean \pm standard 232 error of the estimate of the mean) and uplands $\left(0.25 \pm 0.03 \mathrm{~kg} \mathrm{~m}^{-2}\right)$, using a Welch $t$-test $\left(t_{60}=-0.25 ; p\right.$ $=0.81)$. An ANOVA of ecosite exhibited large but marginally significant declines in litter found in

234 treed poor fens $\left(-0.25 \pm 0.15 \mathrm{~kg} \mathrm{~m}^{-2} ; t=0.09\right)$. Live surface fuels (shrubs, forbes, grass, and sedges) were related solely to drainage class $\left(F_{8,56}=2.86, p=0.01\right)$ but not ecosite. Live fuels were highest in 236 hydric and subhydric drainage classes that were commonly composed of sedges and graminoids (Table 2) with a mean of $0.16 \pm 0.03 \mathrm{~kg} \mathrm{~m}^{-2}$. The lowest live surface fuel load was present in xeric and

238 subxeric systems $\left(0.03 \pm 0.01 \mathrm{~kg} \mathrm{~m}^{-2}\right)$, where live surface fuels (not including lichens) were limited to sparse ericaceous shrubs. An ANOVA of flammable ( $<1 \mathrm{~cm}$ diameter) woody debris by ecosite showed 240 the mean load of $0.02 \pm 0.003 \mathrm{~kg} \mathrm{~m}^{-2}$ increased to $0.07 \pm 0.02 \mathrm{~kg} \mathrm{~m}^{-2}$ in wetland conifer upland ecosites $(t=2.7 ; p=0.007)$. 
Thompson et al. Wildfire fuel loading in boreal wetlands and uplands

Fully 46 of 66 sampled sites had an understory tree fuel load (a component of the surface fuel bed

244 given the low crown base height) of less than $0.01 \mathrm{~kg} \mathrm{~m}^{-2}$. An ANOVA of understory conifer tree loading revealed a significant ecosite effect $\left(F_{7,58}=4.78 ; p<0.001\right)$ that explained $36 \%$ of the total

246 variance. A Tukey's HSD post-hoc test revealed that this difference was largely driven by very high understory fuel loading in the moist conifer uplands ecosites $\left(0.20 \pm 0.07 \mathrm{~kg} \mathrm{~m}^{-2}\right)$, which was

248 dominated by a dense black spruce understory in five of six measured moist conifer upland ecosites, and white spruce in the other. Total fuel load available for surface fires (the sum of litter, live, woody 250 debris $<1.0 \mathrm{~cm}$ and understory pools $)$ was not significantly related to drainage class $\left(F_{8,57}=0.96, p=\right.$ $0.47)$ or ecosite $\left(F_{7,58}=1.03, p=0.42\right)$ with an overall mean of $0.42 \pm 0.03 \mathrm{~kg} \mathrm{~m}^{-2}$ across all ecosites.

252 Of the 66 sites, 33 were treed $(>10 \%$ tree cover and height $>5 \mathrm{~m})$, with a mean canopy fuel load of 1.44 $\pm 0.26 \mathrm{~kg} \mathrm{~m}^{-2}$. Within the treed sites, drainage class did not differ amongst drainage classes $\left(F_{6,26}=\right.$

$2541.24 ; p=0.319$. The largest canopy fuel loads of 5.4 and $5.8 \mathrm{~kg} \mathrm{~m}^{-2}$ were found nearby in the PeaceAthabasca delta in a riparian white spruce stand, as well as in a dense closed-canopy willow floodplain.

Total fuel load (including both surface and canopy fuels) averaged $0.85 \pm 0.20 \mathrm{~kg} \mathrm{~m}^{-2}$ in wetlands, and $258 \quad 1.45 \pm 0.24 \mathrm{~kg} \mathrm{~m}^{-2}$ across uplands. However, when the highest fuel loads found in wet upland conifer forests are excluded, there was no difference between the mean total fuel load in all other upland 260 forests versus all wetlands, with the mean total fuel loading in uplands reduced to $1.15 \pm 0.23 \mathrm{~kg} \mathrm{~m}^{-2}$ $\left(t_{71}=-1.17 ; p=0.26\right)$. Total fuel load in these wet upland conifer forests over 95 years of age was 4.5

$262 \mathrm{~kg} \mathrm{~m}^{-2}$, a nearly four-fold increase over the average fuel load in other upland forests (Table 2).

264 3.3. Observed fuel structure and the Canadian Fire Behaviour Prediction System Mean surface fuel loading in open, treeless wetlands was $0.48 \pm 0.06 \mathrm{~kg} \mathrm{~m}^{-2}, 37 \%$ higher than the 266 standard of $0.35 \mathrm{~kg} \mathrm{~m}^{-2}$ fuel loading for grass fuel (O-1) following the FBP System (Wotton et al. 
Thompson et al. Wildfire fuel loading in boreal wetlands and uplands

2009). While the FBP System assumes low grass curing in mid-summer conditions, we observed a

268 significant litter bed of dead grass and sedge fuel load present amongst live grasses, which lowered the effective moisture content (increased curing) of the fuel bed. The mean ratio of live to litter fuel

270 loading in wetland sites did not differ across wetlands ecosite classes (ANOVA; $F_{3,20}=0.396 ; p=$ 0.757; Figure 3), with a mean of 4 years' worth of litter accumulation found in wetlands (counting only

272 sites greater than six years since fire). This significant litter accumulation was often well-aerated and upwards of $30 \mathrm{~cm}$ in height, and would effectively shift the cured grass portion of the fuel bed to as

274 high as $80 \%$, with four parts litter accumulation and one part live growth.

276 Canopy fuel loads greater than the $1.15 \mathrm{~kg} \mathrm{~m}^{-2}$ from the standard C-3 mature jack pine fuel type from the FBP System were found in 11 of 21 upland stands (Table 1), and were observed in sites as young as

27831 years since fire. Only two forested wetlands exceeded the $0.8 \mathrm{~kg} \mathrm{~m}^{-2}$ of canopy fuel loading from the standard boreal spruce C-2 fuel type (Figure 4). Only 26 of 33 sites with a tree canopy exceeded the 280 approximate minimum crown bulk density of $0.1 \mathrm{~kg} \mathrm{~m}^{-3}$ required to sustain a crown fire (Cruz et al. 2005). Sites with a conifer basal area of less than $10 \mathrm{~m}^{2} \mathrm{ha}^{-1}$ in 8 of 9 cases did not have sufficient 282 canopy bulk density to sustain a crown fire, while sites with greater than $10 \mathrm{~m}^{2} \mathrm{ha}^{-1}$ did in every case. For forested wetlands (excluding those dominated by tall shrubs), a rise in crown base height was 284 observed alongside increasing canopy fuel load (Figure 4). Crown base height in uplands showed no pattern, and varied widely from less than $3 \mathrm{~m}$ to over $17 \mathrm{~m}$ (Figure 4 ).

\section{Discussion}

4.1 A changing boreal fuels mosaic

The results of this study provide further support for the claims of an effect of stand age on wildfires in 
Thompson et al. Wildfire fuel loading in boreal wetlands and uplands

290 the boreal forest. They reaffirm what we know about fuel accumulation in upland boreal forests: rates of accumulation are highly variable, but do, on average take a few decades to reach pre-fire levels.

292 Despite the variability in fuel loads among forest stands, very high levels of biomass are only observed after about 20 years following a fire, which is consistent with the results of Héon et al. (2014) in

294 eastern Canada. Our results suggest that this age dependence, however, only holds true for upland forests in our study area. Fire--vegetation relationships of the lowlands add complexity to landscape 296 dynamics in that, when largely treeless, they have a surface-fire regime that can re-burn only a few years after a fire. This is particularly consequential given the large fraction of the landscape (up to half) covered by wetlands in our study area of Wood Buffalo National Park; as such, recent burns may—on the whole — not provide the degree of resistance to subsequent burning observed elsewhere in the 300 boreal forest (Bernier et al. 2016; Erni et al. 2016).

302 Wetland fuel load and structure are for the first time documented and contrasted with those of upland forests. While fuel loads in these abundant boreal wetlands are often comparable to uplands, site-level 304 differences such as fuel moisture, phenology, and access to groundwater are factors that likely contribute to their widespread burning during periods of profound drought. We found the highest fuel loads in the wet upland conifer ecosite (Table 2) that often lies in the transition zone between wetlands and drier forests that are either deciduous-dominated or else more sparsely treed. In general, fire may

308 be possible in upland forests after only several days of fuel drying, but this is not the case in wetlands, which have a much more restricted window of burning that often negates their availability of

310 flammable biomass. However, during drought conditions some studies report that wetlands are more likely to contribute to burn area (Turetsky et al. 2004; Turetsky et al. 2015). Indeed, the rapid recovery 312 of surface fuels over organic wetland soils documented here may allow for the re-burn of wetland fuels in nearly consecutive years as deeper organic horizons are exposed by a lowered water table. The 
Thompson et al. Wildfire fuel loading in boreal wetlands and uplands

314 extent to which the rapid accumulation of flammable biomass is counteracted by the narrowness of the seasonal burn window in explaining fire activity in wetland ecosystem warrants further study.

The variability in flammable fuels observed in both upland and lowland ecosystems reported in this study highlight the extreme variability that exists in our study area and, as such, caution against drawing steadfast conclusions regarding fire-fuels dynamics. Patterns observed may nevertheless be instructive as to the limits under which the recent burns and wetlands are able to resist subsequent burning. Our results show that the burning of wetlands dominated by graminoids, which is highly dependent of drought recurrence, is not completely independent of fuel succession when these have a tree cover - that is, they can behave as an intermediate between wetland and upland sites. In particular, the potential of high-frequency fire in graminoid-dominated wetlands contrasts strongly with treed and forested wetlands with a Sphagnum moss groundcover, where any significant fire spread is only possible 80 years after fire (Johnston et al. 2015). It should be noted that these ecosystems are viewed with increasing interest in the Boreal Plain of western Canada because they are projected to become an important refugium for conifers under climate change in the region (Schneider et al. 2015).

330 An interesting, if somewhat anecdotal, aspect of the study area is the commonness of surface fires (Figure 2). Although surface fires have been reported as frequent in other parts of the boreal forest 332 (Heinselman 1973), the conceptual fire-regime model for the boreal forest stipulates that the clear majority of the area burned by wildfires is through stand-renewing crown fires (Johnson 1996). Surface

334 fires in the study area occur almost exclusively in pine-dominated stands. These have low surface fuels and vegetation cover, and high (several meters) crown fuel base, factors that contribute to limiting

336 crown involvement. While this remains to be fully assessed, we speculate that stands that repeatedly burn as surface fires do so because of the high frequency of fires - one of the highest of the North 
Thompson et al. Wildfire fuel loading in boreal wetlands and uplands

338 American boreal forest - in this area. The phenomenon may thus be self-reinforcing, as frequent fires further reduce the potential for subsequent crown fires. Our result are coherent with those of other studies that suggest that frequent surface fires may lead to a fuel-accumulation trajectory that is highly divergent from that of stands originating from stand-renewing fires (Miquelajauregui et al. 2016).

From the results of the upland fuel loading observations, white spruce is present in almost all sites

344 showing high fuel loads $\left(>4 \mathrm{~kg} \mathrm{~m}^{-2}\right)$ in this region. White spruce is generally considered to be a climax species that is indicative of long periods since fire, as this shade-tolerant species may succeed after pine on subxeric sites (Purchase and La Roi 1982) and in aspen forest on mesic sites (Rowe 1961), but is considered intolerant to fire disturbance with poor post-fire recruitment (Purdy et al 2002; Johnstone and Chapi 2004). Arguably, these pockets of high fuel load may exist as fire refugia (Raup 1935; Madoui 2011); in this study the mature white spruce stands were found only in areas such as upland islands in the middle of rich fens with low fuel load, in the lee of lakes, and other areas that may provide shelter from advancing wildfire (Larsen 1997).

\subsection{Importance of fuel loading}

354 In this study, we only used surface and canopy fuels capable of flaming consumption, which discounts larger diameter coarse woody debris, as well as duff. Though duff and its moisture content is a vital predictor of lightning fire ignition in boreal Canada (Wotton and Martell 2005), organic soils typically combust in the smouldering phase at rates on the order of $1 \mathrm{~cm} \mathrm{~h}^{-1}$ (Prat et al. 2015) and therefore are unlikely to significantly contribute to the flaming head fire intensity. Experimental burning that measures the depth of burn immediately after the passage of the fire front and before significant smouldering typically records around $1 \mathrm{~kg} \mathrm{~m}^{-2}$ of surface fuel consumption, while data taken from 
Thompson et al. Wildfire fuel loading in boreal wetlands and uplands

paired burned-unburned plots weeks after wildfire shows consumption values closer to $3 \mathrm{~kg} \mathrm{~m}^{-2}$ (de

362 Groot et al. 2009). Following Byram's formulation for fireline intensity (Byram 1959), fuel loading is an independent input to fire intensity alongside a fire's rate of spread and the heat of combustion of the

364 fuels. In this sense, fuel loading as represented here is a proxy for the maximum potential intensity for a given rate of spread, fuel structure, and moisture condition of a fuel bed. Fuel structure in the canopy,

366 in turn, is a critical component of the initiation of crown fire in boreal forests (Van Wagner 1977).

Since crown fire initiation is based on critical surface fire intensity, an increase in the fuel loading at

368 the surface can increase fire intensity beyond the threshold for heating of canopy fuels. Indeed, in the analysis of crown fire initiation probability, Cruz et al. (2004) found that surface fuel consumption

370 played a direct role in determining the probability of crown fire initiation. At a larger scale, Cumming (2001) as well as Krawchuk et al. (2006) found significant differences in lightning fire probability between even black and white spruce stands, suggesting this role of canopy structure and fuel load extends to patterns of lightning fire initiation.

While we have discounted deciduous overstory trees from fuel loading calculations, deciduous shrubs, sedges, and graminoids have been included in fuel loading in this study. Our measurements of shrub fuel loading are inclusive of both live foliage, as well as live and dead branch wood within the shrub canopy. From our measurements of the bulk moisture content within the shrub canopy, we observed that up to half of the branch wood in the wetland shrub canopy (primarily Salix spp. with some Betula spp.) is composed of dead branch wood that is at equilibrium moisture content with the atmosphere, which during wildfire-prone periods is $5-10 \%$ gravimetric moisture content (Amiro et al. 2005). In the context of live deciduous leaves measured in this study at 150-200\% gravimetric moisture content, this results in a canopy moisture content more on the order of 30-80\% gravimetric moisture content, which is lower than or similar to conifer overstories. Similarly, the high litter load relative to live green 
Thompson et al. Wildfire fuel loading in boreal wetlands and uplands

biomass in the sedge and graminoid-dominated wetlands means that even in mid-summer that the

system can sustain at least a low-intensity fire if the litter fuels are sufficiently dry. This contrasts with sub-tropical to semi-arid grasslands, where litter does not generally persist over a year before decomposing, and therefore generally no more than a year's worth of growth is present in the litter layer (Cheney and Sullivan 2008).

\subsection{Relevance to fire behaviour models}

392 A relative invariance of surface fuel loading was observed across a large range of ecosites and time since fire. While the total surface fuel load did not systematically vary across sites, the origin of the

394 surface fuels varied across sites. Xeric sites such as the dry pine-lichen shown here featured high litter loads of lichens and needle litter, while mesic upland sites and forested wetlands featured higher

396 densities of small conifer trees as sources of surface fuel loading. In open wetlands, sedge and graminoid litter was the main source of surface fuels, in addition to short shrubs $<0.5 \mathrm{~m}$ tall.

In additional to the effect on fire intensity, canopy fuel loading has a significant effect on the surface microclimate for litter and duff fuels, an effect observed by Wotton and Beverly (2007). Low light levels at the forest floor promote the expansion and growth of feathermoss at the expense of understory trees, herbs, and shrubs (Bisbee et al. 2001). Despite the lower moisture content of feathermosses compared to forest floor litter layers (Wilmore 2001), lower surface wind speeds (Massman 1997)

404 caused by high wind attenuation in the canopy may somewhat ameliorate this effect. Future improvements to fire behaviour models in Canada would benefit from being adaptive to the large variation in canopy fuel load and structure. 
Thompson et al. Wildfire fuel loading in boreal wetlands and uplands

\section{5. Conclusions}

Wildfire fuel loading was assessed across 66 plots following a gradient of drainage and time since fire.

410 By far the highest fuel loads were observed in moist white spruce upland forests where fuel loading exceeded $5 \mathrm{~kg} \mathrm{~m}^{-2}$ at times, fully four times greater than the standard boreal spruce fuel model

412 (Forestry Canada Fire Danger Group 1992). Notwithstanding densely stocked spruce stands, total fuel loading across the rest of the range of ecosites and ages varied relatively little between 0.8 and $1.2 \mathrm{~kg} \mathrm{~m}^{-}$

$412^{2}$, and fell within the range of standard fuel models in the Canadian Fire Behaviour Prediction System. Wetlands, inclusive of treed, shrub, and sedge-dominated, showed no substantial difference in total fuel 416 loading compared to most uplands owing to substantial accumulations of litter and small conifers. The fuel load observations made here are evidence of wetlands in this region having largely similar fuel

418 loads as uplands, if all the wetland fuels are considered available for flaming combustion. The quantification of wetland fuels presented here made without regard to the moisture status of the fuels

420 and represent maximum fuel availability during drought. The rate and patterns of landscape fuel availability during periods of increasing is poorly parametrized in current fire behaviour and fuel 422 consumption models.

424 The measurements are representative of the current climate, and do not attempt to normalize post-fire fuel loading as a response to variable fire severity. With a more severe fire regime being a likely future 426 for the boreal forest (Boulanger et al. 2013), the feedback of increased fire severity on post-fire fuel accumulation and recovery remains to be tested under a new climate. In the dry conifer forests of the southwestern USA where climate change is almost certain to reduce productivity due to water limitation, increased fire frequency in a future warmer climate may create a strong fire-fuels negative 430 feedback, with less fuels on the landscape as a result (Diggins et al. 2010). Future ecosystem 
Thompson et al. Wildfire fuel loading in boreal wetlands and uplands

trajectories in this wetland-abundant region are less certain (Schneider et al. 2015), as wetlands are

432 likely to show a lagged vegetation response to climate change. In our study area, although many vegetation types appear to exhibit a rapid recovery of fuels following wildfire, it is still uncertain to

434 what extent variable fuel recovery rates limit subsequent wildfire activity, as reported by Héon et al. (2014). A recent broad-scale study (Price et al. 2015) in Alberta did not observe such a dependence, but 436 this may be due to the broad-scaled nature of the analysis, as well as a strong anthropogenic effect on fire activity, which is largely absent from our study area. While this study examines the accumulation 438 of wildfire fuels as a function of time since fire, future research is required to better understand fire behaviour and controls on post-fire vegetation succession in the Boreal Plains, particularly under 440 extreme weather conditions.

\section{6. Acknowledgements}

Fieldwork assistance was provided by Mike Michaelian, Doug Stiff, Tom Fleming, and Jim Weber.

444 Additional tree disk preparation was provided by Nick Poischente. Numerous Parks Canada staff assisted in the access to remote sites within the park. Tom Schiks provided valuable feedback on an 446 earlier version of the manuscript.

\section{References}

Alexander, M.E., Stefner, C.N., Mason, J.A., Stocks, B.J., Hartley, G. R., Maffey, M.E., Wotton, B.M., 450 Taylor, S.W., Lavoie, N., and Dalrymple, G.N. 2004. Characterizing the Jack Pine - Black Spruce Fuel Complex of the International Crown Fire Modelling Experiment (ICFME). Can. Forest. Serv. 452 Inf. Rep. NOR-X-393.

Amiro, B. D., Logan, K. A., Wotton, B. M., Flannigan, M. D., Todd, J. B., Stocks, B. J., and Martell, D. 
Thompson et al. Wildfire fuel loading in boreal wetlands and uplands

454 L. (2005). Fire weather index system components for large fires in the Canadian boreal forest. Int. J. Wildland Fire 13: 391-400.

456 Beckingham, J.D., and Archibald, J.H. (1996). Field guide to ecosites of Northern Alberta. Can. Forest. Serv., North. For. Cent., Edmonton, Alberta. Special Report 5.

458 Bernier, P. Y., Gauthier, S., Jean, P. O., Manka, F., Boulanger, Y., Beaudoin, A., and Guindon, L. (2016). Mapping local effects of forest properties on fire risk across Canada. Forests 7: 157. 460 doi:10.3390/f7080157

Benscoter, B. W., and Wieder, R. K. (2003). Variability in organic matter lost by combustion in a boreal 462 bog during the 2001 Chisholm fire, Can. J. For. Res. 33: 2509-2513.

Bessie, W. C., and Johnson, E. A. (1995). The relative importance of fuels and weather on fire behavior 464 in subalpine forests. Ecology 76: 747-762.

Bisbee, K. E., Gower, S. T., Norman, J. M., and Nordheim, E. V. (2001). Environmental controls on 466 ground cover species composition and productivity in a boreal black spruce forest. Oecologia, 129: 261-270.

468 Boulanger, Y., Gauthier, S., Gray, D. R., Le Goff, H., Lefort, P., and Morissette, J. (2013). Fire regime zonation under current and future climate over eastern Canada. Ecol. Appl. 23: 904-923. Doi:

$470 \quad 10.1890 / 12-0698.1$.

Byram, G.M. 1959. Combustion of forest fuels. In Forest Fire: Control and Use. McGraw-Hill, New $472 \quad$ York. pp. 61-89.

Cheney, P., Sullivan, A. 2008. Grassfires: fuel, weather, and fire behaviour. Second Edition. CSIRO 474 Publishing, Collingwood, Australia. 160 pp. 
Thompson et al. Wildfire fuel loading in boreal wetlands and uplands

Cieszewski, C., Bella, I.E., and Yeung, D.P. 1993. Preliminary site-index height growth curves for 476 eleven timber species in Saskatchewan. Draft unpublished project report. Canada-Saskatchewan Partnership Agreement in Forestry. Nat. Resour. Can., Can. Forest. Serv., Prince Alberta, Sask. pp. 1-

6.

Cruz, M. G., Alexander, M. E., and Wakimoto, R. H. (2005). Development and testing of models for predicting crown fire rate of spread in conifer forest stands. Can. J. Forest Res. 35: 1626-1639.

Cumming, S. G. (2001). Forest type and wildfire in the Alberta boreal mixedwood: what do fires burn? $482 \quad$ Ecol. Appl. 11: 97-110.

de Groot, W. J., Pritchard, J. M., and Lynham, T.J. (2009). Forest floor fuel consumption and carbon 484

Diggins, C., Fulé, P. Z., Kaye, J. P., and Covington, W. W. (2010). Future climate affects management 486 strategies for maintaining forest restoration treatments. Int. J. Wildland Fire 19: 903-913. doi: 10.1071/WF09109.

Downing, D.J., Pettapiece, W.W. (2005). Natural Regions and Subregions of Alberta. Natural Regions Committee: Government of Alberta, Alberta, Canada Pub. No. T/852.

490 Ecological Stratification Working Group (1996). A National Ecological Framework for Canada. Agriculture and Agri-Food Canada, Research Branch, Centre for Land and Biological Resource 492 Research and Environment Canada, State of the Environment Directorate, Ecozone Analysis Branch, Ottawa/Hull. 125 pp. Map at 1: 7,500,000.

494 Environment and Climate Change Canada. (2015). Canadian Climate Normals 1981-2010 Station Data: Fort Smith, NT. 
Thompson et al. Wildfire fuel loading in boreal wetlands and uplands

496 http://climate.weather.gc.ca/climate_normals/results_1981_2010_e.html?stnID=1660 [accessed 2016-04-27]

498 Erni, S., Arseneault, D., Parisien, M.A. and Begin, Y., (2016). Spatial and temporal dimensions of fire activity in the fire-prone eastern Canadian taiga. Glob. Change Biol. 23:1152-1166. doi:

$500 \quad 10.1111 / \mathrm{gcb} .13461$.

Fenton, M.M. Waters, E.J. Pawley, S.M. Atkinson, N. Utting, D.J. Mckay, K. (2013). Surficial Geology 502 of Alberta. Alberta Geological Survey: Edmonton, Canada. Map 601.

Flannigan, M., Cantin, A. S., de Groot, W. J., Wotton, M., Newbery, A., and Gowman, L. M. (2013).

504 Global wildland fire season severity in the 21 st century. Forest Ecol. Manag. 294: 54-61. doi: 10.1016/j.foreco.2012.10.022

506 Forestry Canada Fire Danger Rating Group (1992). Development and Structure of the Canadian Forest Fire Behavior Prediction System. Forestry Canada, Ottawa. Information Report ST-X-3. 64 p.

508 Frandsen, W. H. (1998). Heat flow measurements from smoldering porous fuel. Int. J. Wildland Fire 8: 137-145.

510 Ganteaume, A., Jappiot, M., Lampin, C., Guijarro, M., and Hernando, C. (2013). Flammability of some ornamental species in wildland-urban interfaces in southeastern France: laboratory assessment at 512 particle level. Env. Manag. 52: 467-480. doi: 10.1007/s00267-013-0067-Z.

Hare, F.K. (1980). Long-term Annual Surface Heat and Water Balances over Canada and the United 514 States South of $60^{\circ} \mathrm{N}$ : Reconciliation of Precipitation, Runoff and Temperature Fields. Atmos. Ocean. 18: $127-153$.

516 Heginbottom, J. A. (1995). Canada-permafrost. The National Atlas of Canada, Map MCR 4177F 1: 1 
Thompson et al. Wildfire fuel loading in boreal wetlands and uplands

750000 scale. Natural Resources Canada, Geological Survey of Canada: Ottawa.

518 Hellberg, E., Niklasson, M. and Granström, A. (2004). Influence of landscape structure on patterns of forest fires in boreal forest landscapes in Sweden. Can. J. Forest Res. 34, 332-338.

520 Héon, J., Arseneault, D., and Parisien, M. A. (2014). Resistance of the boreal forest to high burn rates. P. Natl. Acad. Sci. 111: 13888-13893. doi: 10.1073/pnas.1409316111.

522 Johnson, E.A., 1996. Fire and Vegetation Dynamics: studies from the North American boreal forest. Cambridge University Press. 125 pp.

524 Johnston, D. C., Turetsky, M. R., Benscoter, B. W., and Wotton, B. M. (2015). Fuel load, structure, and potential fire behaviour in black spruce bogs. Can. J. Forest Res., 45: 888-899. doi: 10.1139/cjfr$526 \quad 2014-0334$.

Johnstone, J. F., and Chapin III, F. S. (2006). Fire interval effects on successional trajectory in boreal 528 forests of northwest Canada. Ecosys. 9: 268-277.

Krawchuk, M. A., Cumming, S. G., Flannigan, M. D., and Wein, R. W. (2006). Biotic and abiotic 530 regulation of lightning fire initiation in the mixedwood boreal forest. Ecol. 87: 458-468.

Larsen, C.P.S. (1997). Spatial and temporal variations in boreal forest fire frequency in northern 532 Alberta. J. Biogeog. 24: 663-673.

Larsen, C. P. S., and MacDonald, G. M. (1998). An 840-year record of fire and vegetation in a boreal 534 spruce forest. Ecol. 79: 106-118.

Lavoie, N., Alexander, M. E., and Macdonald, S. E. (2010). Photo Guide for Quantitatively Assessing 536 the Characteristics of Forest Fuels in a Jack Pine - Black Spruce Chronosequence in the Northwest Territories. Can. Forest. Serv. Info. Rep. NOR-X-419. 51 p. 
Thompson et al. Wildfire fuel loading in boreal wetlands and uplands

538 Lukenbach, M. C., Hokanson, K. J., Moore, P. A., Devito, K. J., Kettridge, N., Thompson, D. K., Wotton, B.M., Petrone, R.M., Waddington, J. M. (2015). Hydrological controls on deep burning in a 540 northern forested peatland. Hydrol. Proc. 29, 4114-4124.

Madoui, A., Leduc, A., Gauthier, S., and Bergeron, Y. (2011). Spatial pattern analyses of post-fire 542 residual stands in the black spruce boreal forest of western Quebec. Int. J. Wildland Fir 19: 11101126. doi: 10.1071/WF10049.

544 Massman, W. J. (1997). An analytical one-dimensional model of momentum transfer by vegetation of arbitrary structure. Bound. Lay. Meteorol. 83: 407-421.

546 McRae, D.J., Alexander, M.E., and Stocks, B.J. 1979. Measurement and Description of Fuels and Fire Behaviour on Prescribed Burns: a handbook. Can. Forest. Serv. Great Lakes For. Cent. Info. Rep. No. O-X-287.

Miquelajauregui, Y., Cumming, S.G. and Gauthier, S., (2016). Modelling variable fire severity in boreal 550 forests: effects of fire intensity and stand structure. PLoS One 11: p.e0150073.

Natural Resources Canada. (2016). Canadian National Fire Database.

552 http://cwfis.cfs.nrcan.gc.ca/ha/nfdb (access March 29, 2016).

Niklasson, M., and Granström, A. (2000). Numbers and sizes of fires: long-term spatially explicit fire 554 history in a Swedish boreal landscape. Ecol. 81: 1484-1499.

Prat, N., Belcher, C. M., Hadden, R. M., Rein, G., and Yearsley, J. M. (2015). A laboratory study of the 556 effect of moisture content on the spread of smouldering in peat fires. FLAMMA 6: 35-38.

Price, O. F., Pausas, J. G., Govender, N., Flannigan, M., Fernandes, P. M., Brooks, M. L., Bird, R. B. 558 (2015). Global patterns in fire leverage: the response of annual area burnt to previous fire. Int. J. 
Thompson et al. Wildfire fuel loading in boreal wetlands and uplands

Wildland Fire 24: 297-306. doi: 10.1071/WF14034.

560 Priyadarshana, W. J. R. M., Sofronov G. (2015). Multiple Break-Points Detection in Array CGH Data via the Cross-Entropy Method, IEEE/ACM Transactions on Computational Biology and Bioinform.

562 12: $487-498$.

Purchase, J. E., and Roi, G. H. L. (1983). Pinus banksiana forests of the Fort Vermilion area, northern

564 Alberta. Can. J. Bot. 61: 804-824.

Purdy, B. G., Macdonald, S. E., and Dale, M. R. (2002). The regeneration niche of white spruce

566 following fire in the mixedwood boreal forest. Silva Fenn. 36: 289-306.

R Core Team. (2016). R: A Language and Environmental for Statistical Computing. R Foundation for 568 Statistical Computing. Vienna: Austria.

Raup, H.M. 1935. Botanical Investigations in Wood Buffalo National Park. Ottawa, National Museum 570 of Canada.

Rowe, J.S. (1961). Critique of some vegetational concepts as applied to forests of northwestern Alberta.

572 Can. J. Botany 39: 1007-1017.

Schiks, T. J., Wotton, B. M., Turetsky, M. R., and Benscoter, B. (2016). Variation in fuel structure of 574 boreal fens. Can. J. Forest Res. 46: 683-695. doi: 10.1139/cjfr-2015-0445.

Schneider, R. R., Devito, K., Kettridge, N., and Bayne, E. (2015). Moving beyond bioclimatic envelope 576 models: integrating upland forest and peatland processes to predict ecosystem transitions under climate change in the western Canadian boreal plain. Ecohydrol. 9: 899-908. doi: 10.1002/eco.1707

578 Schwarz, A.G. 1994. Inventory of Dry Grasslands and Associated Vegetation in Wood Buffalo National Park. Canadian Circumpolar Institute, University of Alberta, Edmonton, Canada. 29 pp. 
Thompson et al. Wildfire fuel loading in boreal wetlands and uplands

580 Schimmel, J., and Granström, A. (1997). Fuel succession and fire behavior in the Swedish boreal forest. Can. J. Forest Res. 27: 1207-1216.

582 Tarnocai, C, Kettles, I M, Lacelle, B. (2011). Peatlands of Canada. Geological Survey of Canada, Open File 6561, doi:10.4095/288786.

584 Terrier, A., Paquette, M., Gauthier, S., Girardin, M. P., Pelletier-Bergeron, S., and Bergeron, Y. (2016). Influence of fuel load dynamics on carbon emission by wildfires in the Clay Belt boreal landscape.

$586 \quad$ Forests 8: 9. doi: 10.3390/f8010009.

Turetsky, M. R., Amiro, B. D., Bosch, E., and Bhatti, J. S. (2004). Historical burn area in western 588 Canadian peatlands and its relationship to fire weather indices. Global Biogeochem. Cyc. 18. doi:10.1038/ngeo2325.

590 Turetsky, M. R., Benscoter, B., Page, S., Rein, G., van der Werf, G. R., and Watts, A. (2015). Global vulnerability of peatlands to fire and carbon loss. Nature Geosci., 8: 11-14.

592 Van Wagner, C. V. (1977). Conditions for the start and spread of crown fire. Can. J. Forest Res., 7: 2334.

594 Wallenius, T. H., Pennanen, J., and Burton, P. J. (2011). Long-term decreasing trend in forest fires in northwestern Canada. Ecosphere 2: 1-16.

596 Wilmore, B. 2001. Duff Moisture Dynamics in Black Spruce Feather Moss Stands and Their Relation to the Canadian Forest Fire Danger Rating System. M.S. thesis, University of Alaska Fairbanks.

598 Wotton, B. M., and Martell, D. L. (2005). A lightning fire occurrence model for Ontario. Can. J. Forest Res. 35: 1389-1401. 
Thompson et al. Wildfire fuel loading in boreal wetlands and uplands

600 Wotton, B. M., Alexander, M. E., Taylor, S. W. (2009). Updates and Revisions to the 1992 Canadian

Forest Fire Behavior Prediction System. Can. Forest Serv. Info. Rep. GLC-X-10. 
Thompson et al. Wildfire fuel loading in boreal wetlands and uplands

602 List of Tables

Table 1. Breakpoint statistics showing the time since fire where a marked increase in mean surface, 604 canopy, and total fuel load was observed. Mean $(\overline{\boldsymbol{x}})$ and standard deviation $(s)$ before $\left(\overline{\boldsymbol{x}}_{1}\right)$ and after $\left(\overline{\boldsymbol{x}}_{2}\right)$ the breakpoint is shown, as is a Welch's $t$-test for differences in means between the two samples. 606 Comparison with Fire Behaviour Prediction (FBP) system fuel types are also shown. Note that FBP surface fuel load estimates include duff consumption in the flaming phase, which was not considered 608 in the wetland and upland fuel load measurement performed in this study.

610 Table 2. Summary of fuel loading by ecosite and age class. WD represents woody debris with diameter less than $1 \mathrm{~cm}$.

612

List of Figures

614 Figure 1. Map of Wood Buffalo National Park, showing wetland and upland sampling locations. The extent of sampled fires with mapped perimeters is also shown.

616 Figure 2. Fuel accumulation in canopy and surface fuels as a function of time since fire. The time axis is transformed by the natural log for clarity. For reference, the canopy fuel loads in C-2 and C-3 fuels are 0.8 and $1.15 \mathrm{~kg} \mathrm{~m}^{-2}$. Sites with evidence of recent surface fire are denoted with an asterisk.

Figure 3. The ratio of measured surface litter to live surface fuel load in open wetlands. This sum is 620 inclusive of sedges, grasses, and short shrubs $<1.5 \mathrm{~m}$ in height.

Figure 4. The relationship between canopy fuel load and crown base height of conifers (calculated as 622 the Lorey crown base height). Crown base height and bulk density standard values for C-2 (boreal 
Thompson et al. Wildfire fuel loading in boreal wetlands and uplands spruce) and C-3 (mature pine) fuel types are shown as dashed lines.

624 


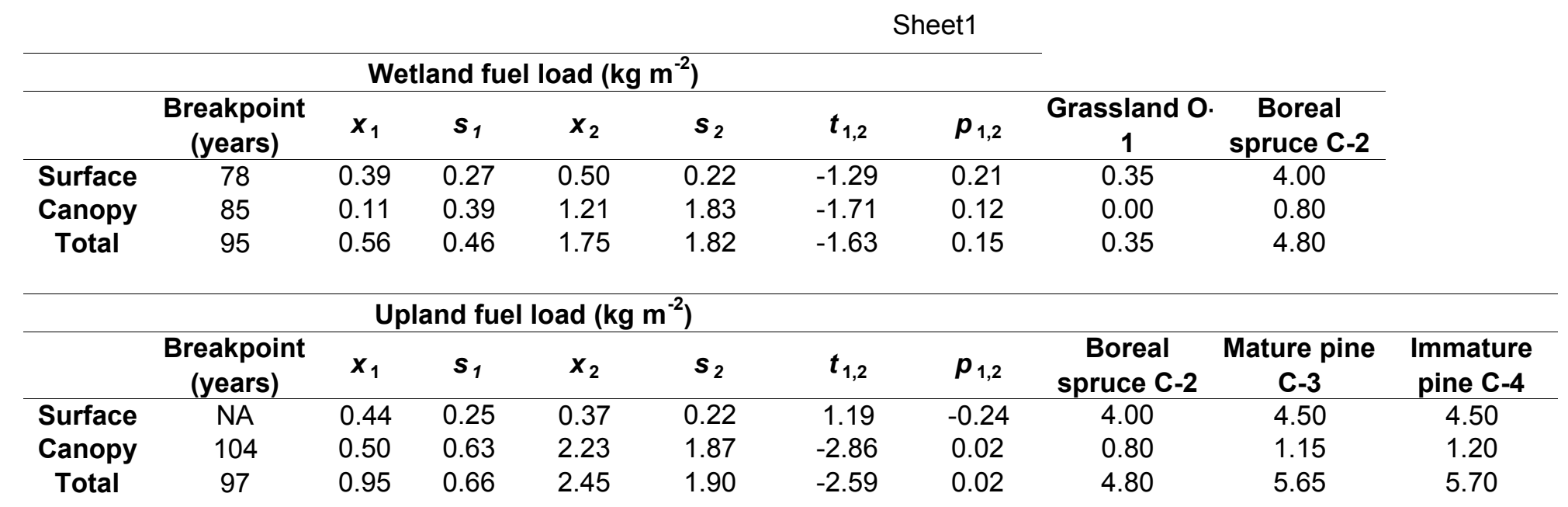


Sheet 1

\begin{tabular}{|c|c|c|c|c|c|c|c|c|c|c|c|}
\hline $\begin{array}{c}\text { Time Since } \\
\text { Fire }\end{array}$ & Ecosite & Ecosite & $n$ & Litter & $\begin{array}{l}\text { Wood } \\
\text { Debris }\end{array}$ & Live & Shrub & $\begin{array}{l}\text { Under } \\
\mathrm{kg} \mathrm{m}^{-2}\end{array}$ & $\Sigma$ Surface & $\Sigma$ Crown & $\Sigma$ Fuel \\
\hline \multicolumn{12}{|l|}{ Uplands } \\
\hline $1-95$ & Dry pine-lichen & a & 7 & 0.31 & 0.03 & 0.03 & 0.00 & 0.10 & 0.48 & 0.73 & 1.21 \\
\hline $95-128$ & & a & 1 & 0.10 & 0.14 & 0.02 & 0.00 & 0.00 & 0.26 & 1.52 & 1.78 \\
\hline 1-95 & Pine mixedwood & $b$ & 5 & 0.24 & 0.03 & 0.11 & 0.00 & 0.01 & 0.39 & 1.09 & 1.48 \\
\hline $95-146$ & & $\mathrm{~b}$ & 3 & 0.23 & 0.02 & 0.05 & 0.00 & 0.01 & 0.31 & 0.94 & 1.25 \\
\hline $1-95$ & Mesic upland & d & 5 & 0.18 & 0.03 & 0.12 & 0.00 & 0.00 & 0.34 & 0.91 & 1.25 \\
\hline $1-95$ & Moist upland conifer & $g$ & 3 & 0.29 & 0.06 & 0.07 & 0.00 & 0.23 & 0.65 & 0.35 & 1.01 \\
\hline $95-155$ & & $g$ & 4 & 0.21 & 0.04 & 0.06 & 0.00 & 0.13 & 0.43 & 4.11 & 4.54 \\
\hline \multicolumn{12}{|l|}{ Wetlands } \\
\hline $1-97$ & Bog & $\mathrm{i}$ & 7 & 0.16 & 0.02 & 0.14 & 0.00 & 0.08 & 0.39 & 0.09 & 0.48 \\
\hline $1-97$ & Treed fen & $\mathrm{j}$ & 4 & 0.08 & 0.00 & 0.10 & 0.02 & 0.03 & 0.23 & 0.59 & 0.81 \\
\hline $97-113$ & & j & 1 & 0.06 & 0.04 & 0.10 & 0.00 & 0.02 & 0.22 & 0.55 & 0.77 \\
\hline $1-97$ & Open fen & $\mathrm{k}$ & 11 & 0.35 & 0.00 & 0.18 & 0.03 & 0.00 & 0.56 & 0.00 & 0.56 \\
\hline $1-97$ & Saline wet meadow & I & 4 & 0.18 & 0.00 & 0.20 & 0.00 & 0.00 & 0.38 & 0.00 & 0.38 \\
\hline $97-250$ & & I & 1 & 0.21 & 0.05 & 0.16 & 0.00 & 0.05 & 0.47 & 1.61 & 2.08 \\
\hline
\end{tabular}




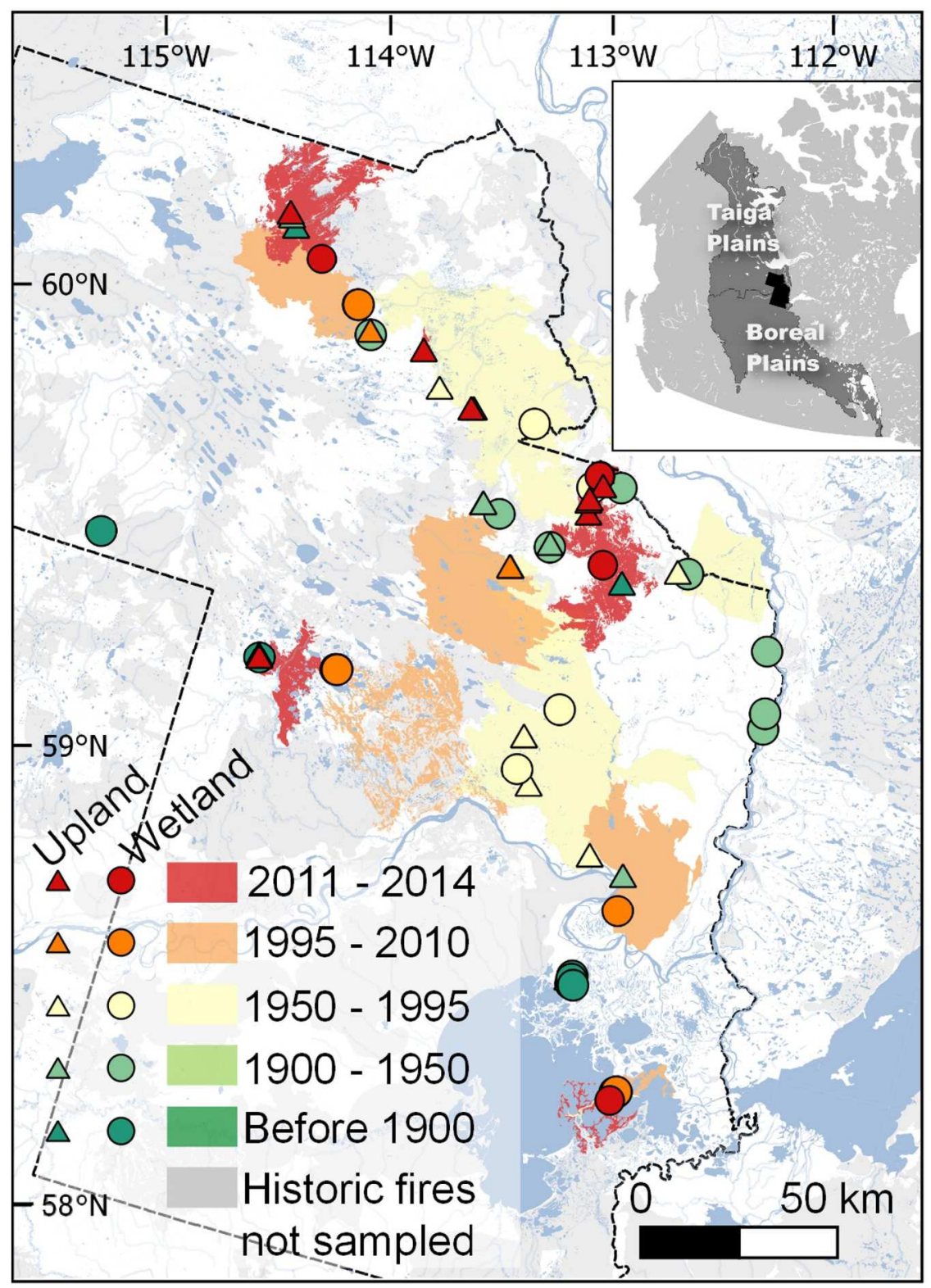

Map of Wood Buffalo National Park, showing wetland and upland sampling locations. The extent of sampled fires with mapped perimeters is also shown.

$125 \times 175 \mathrm{~mm}(300 \times 300 \mathrm{DPI})$ 


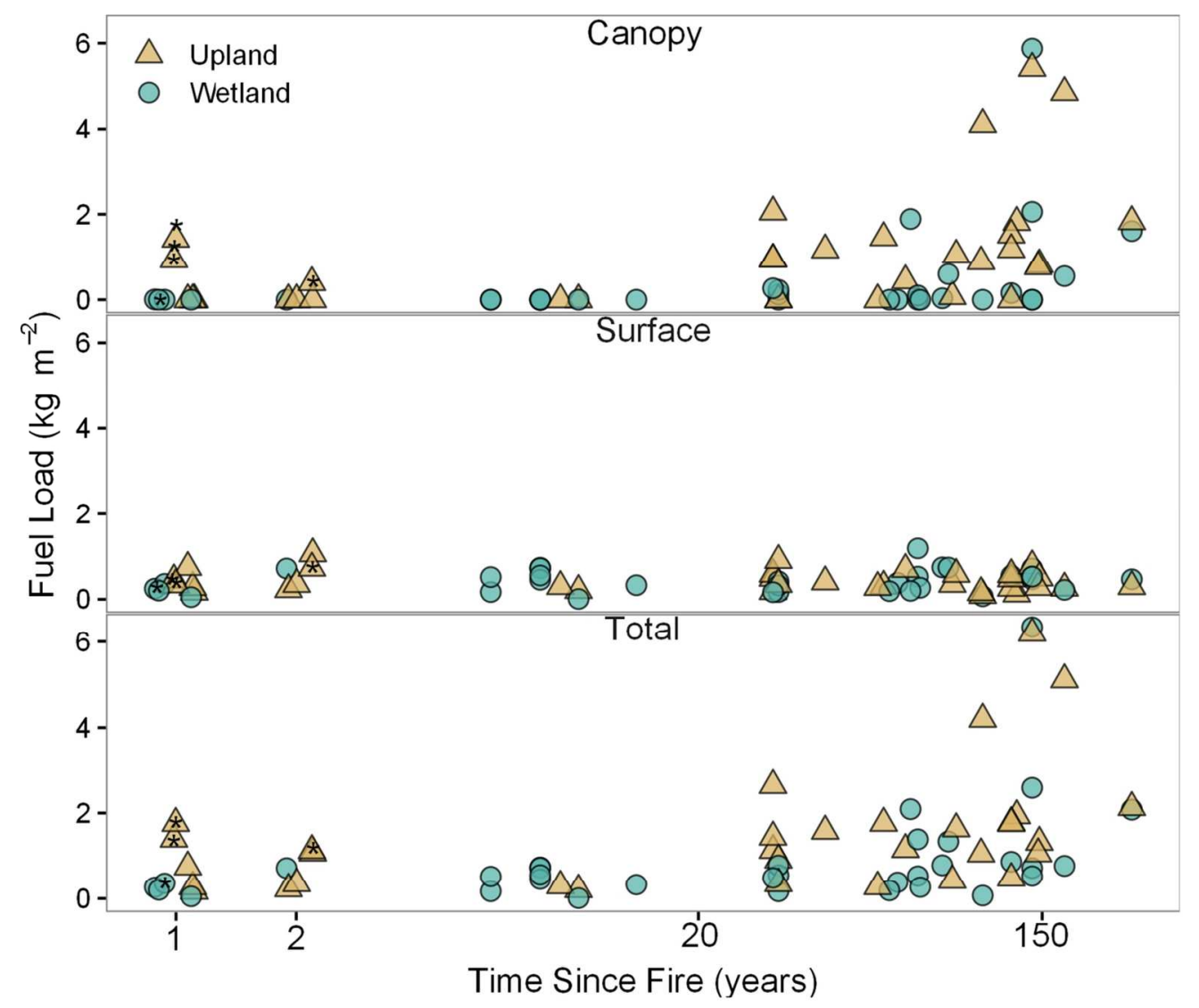

Fuel accumulation in canopy and surface fuels as a function of time since fire. The time axis is transformed by the natural log for clarity. For reference, the canopy fuel loads in C-2 and C-3 fuels are 0.8 and $1.15 \mathrm{~kg}$ $\mathrm{m}^{-2}$. Sites with evidence of recent surface fire are denoted with an asterisk.

$124 \times 105 \mathrm{~mm}(300 \times 300 \mathrm{DPI})$ 


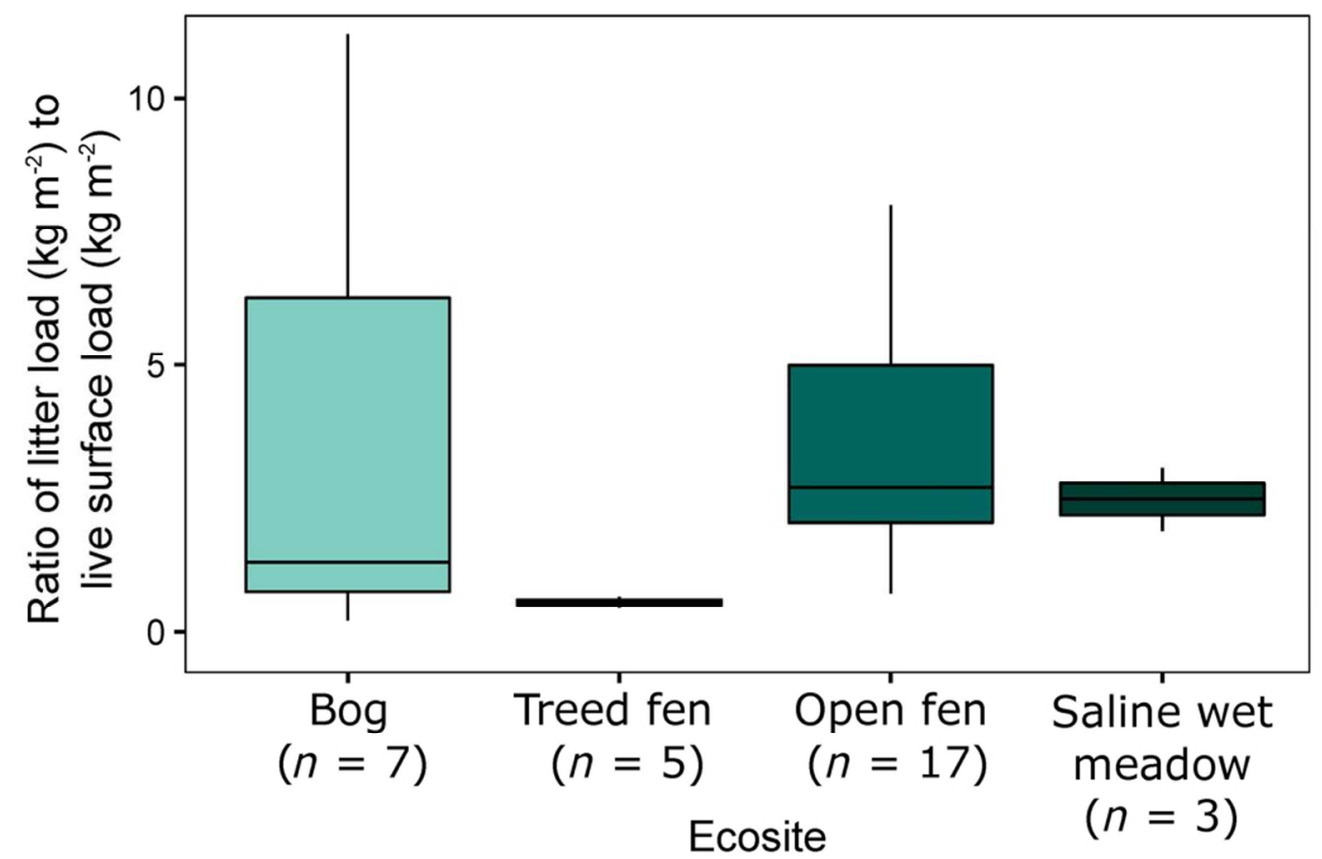

The ratio of measured surface litter to live surface fuel load in open wetlands. This sum is inclusive of sedges, grasses, and short shrubs $<1.5 \mathrm{~m}$ in height.

$87 \times 58 \mathrm{~mm}(300 \times 300$ DPI $)$ 


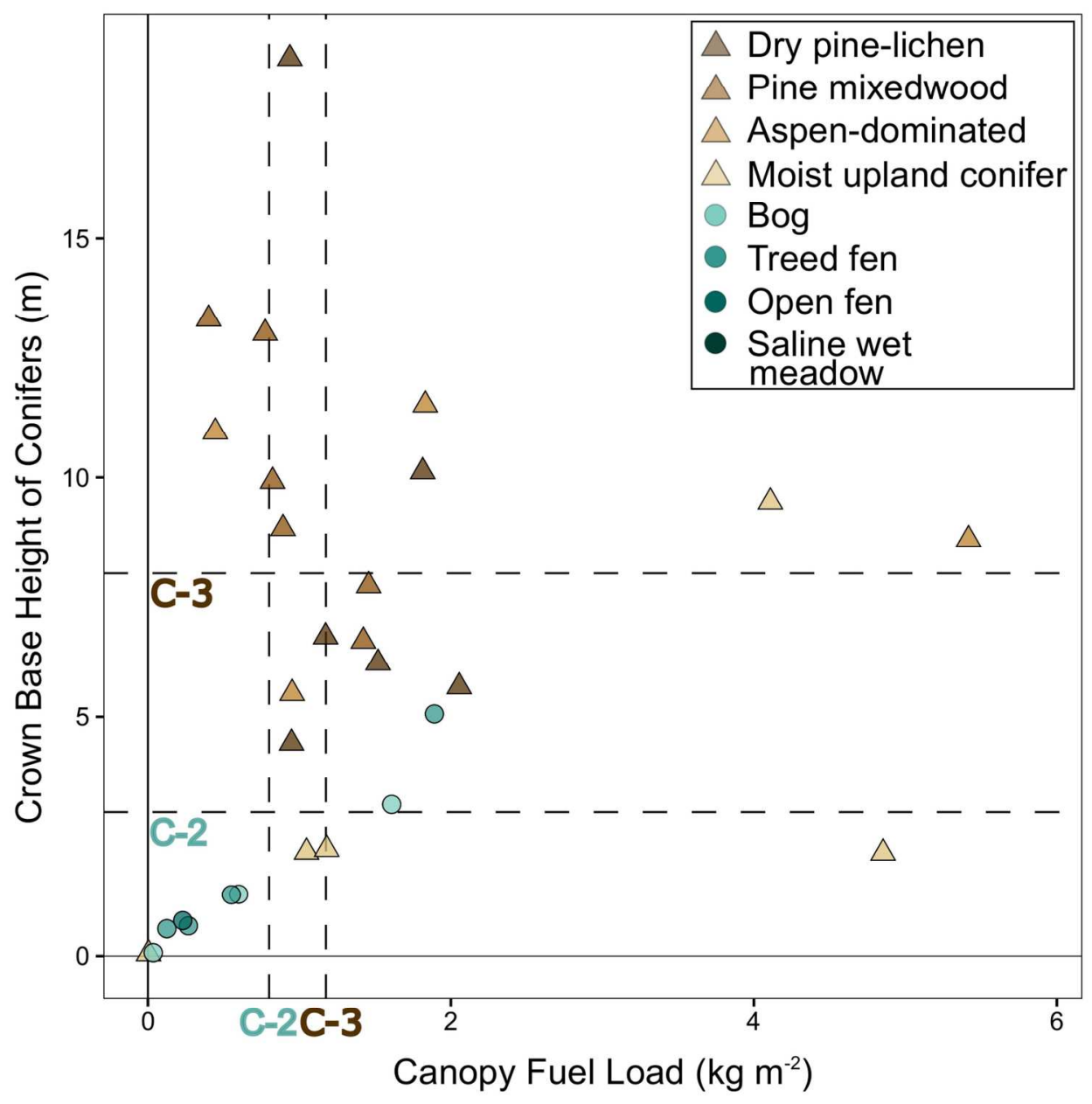

The relationship between canopy fuel load and crown base height of conifers (calculated as the Lorey crown base height). Crown base height and bulk density standard values for C-2 (boreal spruce) and C-3 (mature pine) fuel types are shown as dashed lines.

$159 \times 160 \mathrm{~mm}(300 \times 300 \mathrm{DPI})$ 


\begin{tabular}{|c|c|c|c|c|c|c|c|c|c|c|c|c|c|}
\hline Site & Lat & Long & $\begin{array}{c}\text { Time Since } \\
\text { Fire }\end{array}$ & Drainage & Ecosite & Litter & $\begin{array}{l}\text { Wood } \\
\text { Debris }\end{array}$ & Live & Shrub & $\begin{array}{l}\text { Under } \\
\mathrm{kg} \mathrm{m}^{-2}\end{array}$ & $\Sigma$ Surface & $\Sigma$ Crown & $\Sigma$ Fuel \\
\hline $14-07$ & 59.876 & -112.471 & $1^{*}$ & subxeric & a & 0.34 & 0.01 & 0.10 & 0.00 & 0.01 & 0.46 & 0.94 & 0.46 \\
\hline 4-08 & 9.904 & -112.486 & 1 & subxeric & a & 0.27 & 0.01 & 0.00 & 0.00 & 0.00 & 0.28 & 0.00 & 0.28 \\
\hline $13-01$ & 59.711 & -112.748 & 10 & xeric & a & 0.16 & 0.02 & 0.02 & 0.00 & 0.01 & 0.21 & 0.00 & 0.21 \\
\hline 13-16 & 59.126 & -112.055 & 14 & xeric & a & 0.39 & 0.04 & 0.08 & 0.00 & 0.40 & 0.91 & 0.00 & .31 \\
\hline 12-03 & 60.045 & -112.820 & 31 & subxeric & a & 0.13 & 0.07 & 0.00 & 0.00 & 0.30 & 0.50 & 0.95 & .44 \\
\hline $12-05$ & 59.244 & -112.401 & 31 & subxeric & a & 0.55 & 0.03 & 0.00 & 0.00 & 0.01 & 0.59 & 2.08 & 2.67 \\
\hline 13-02 & 59.711 & -112.745 & 42 & subxeric & a & 0.34 & 0.04 & 0.03 & 0.00 & 0.00 & 0.41 & 1.17 & 1.58 \\
\hline $13-10$ & 59.826 & -112.863 & $124^{1}$ & subxeric & a & 0.10 & 0.14 & 0.02 & 0.00 & 0.00 & 0.26 & 1.52 & 1.78 \\
\hline $12-01$ & 59.743 & -112.240 & 128 & subxeric & a & 0.11 & 0.01 & 0.00 & 0.00 & 0.01 & 0.13 & 1.81 & 1.94 \\
\hline $14-10$ & 60.343 & -114.169 & 1 & submesic & $b$ & 0.65 & 0.00 & 0.07 & 0.00 & 0.03 & 0.75 & 0.00 & 0.75 \\
\hline $14-19$ & 59.910 & -112.484 & $1^{*}$ & subxeric & b & 0.33 & 0.00 & 0.01 & 0.00 & 0.00 & 0.34 & 1.42 & 0.34 \\
\hline $13-26$ & 60.132 & -113.400 & 2 & subxeric & b & 0.07 & 0.05 & 0.11 & 0.00 & 0.00 & 0.23 & 0.00 & 0.23 \\
\hline $14-15$ & 59.946 & -112.441 & $2^{*}$ & submesic & b & 0.30 & 0.07 & 0.36 & 0.00 & 0.00 & 0.73 & 0.63 & 0.73 \\
\hline $13-23$ & 59.349 & -112.479 & 32 & subxeric & $b$ & 0.30 & 0.01 & 0.04 & 0.00 & 0.00 & 0.35 & 0.83 & 0.35 \\
\hline $12-11$ & 59.801 & -112.009 & 59 & mesic & $\mathrm{b}$ & 0.21 & 0.04 & 0.02 & 0.00 & 0.04 & 0.31 & 2.57 & 2.87 \\
\hline $14-12$ & 60.336 & -114.158 & 104 & submesic & $\mathrm{b}$ & 0.08 & 0.02 & 0.03 & 0.00 & 0.03 & 0.16 & 0.89 & 1.07 \\
\hline $14-16$ & 59.947 & -112.448 & $145^{2}$ & submesic & $b$ & 0.20 & 0.02 & 0.06 & 0.00 & 0.00 & 0.28 & 1.11 & 1.05 \\
\hline $14-11$ & 60.316 & -114.126 & 146 & submesic & $b$ & 0.41 & 0.02 & 0.06 & 0.00 & 0.01 & 0. & 0.82 & 1.34 \\
\hline $13-17$ & 59.976 & -112.469 & 1 & mesic & $d$ & 0.11 & 0.05 & 0.01 & 0.00 & 0.00 & 0. & 0.00 & 0.17 \\
\hline $14-04$ & 59.352 & -113.713 & 2 & mesic & $d$ & 0.30 & 0.02 & 0.03 & 0.00 & 0.00 & 0.3 & 0.01 & 0.35 \\
\hline $12-02$ & 60.045 & -112.820 & 31 & mesic & $d$ & 0.17 & 0.01 & 0.00 & 0.00 & 0.00 & 0.18 & 1.47 & 1.66 \\
\hline $14-21$ & 60.059 & -113.282 & $57^{3}$ & mesic & $d$ & 0.21 & 0.03 & 0.04 & 0.00 & 0.00 & 0.28 & 1.73 & 0.28 \\
\hline $13-21$ & 59.947 & -112.490 & 67 & mesic & $d$ & 0.13 & 0.03 & 0.54 & 0.01 & 0.00 & 0.71 & 1.33 & 1.16 \\
\hline $13-12$ & 59.834 & -112.945 & 124 & mesic & $d$ & 0.38 & 0.04 & 0.06 & 0.00 & 0.00 & 0.48 & 1.21 & 0.48 \\
\hline $13-15$ & 59.101 & -111.889 & $145^{3}$ & mesic & $d$ & 0.28 & 0.02 & 0.05 & 0.00 & 0.00 & 0.35 & 1.51 & 0.43 \\
\hline $14-05$ & 59.358 & -113.718 & $250^{4}$ & mesic & $d$ & 0.15 & 0.04 & 0.11 & 0.00 & 0.00 & 0.30 & 2.17 & 2.13 \\
\hline $13-29$ & 58.843 & -112.006 & $155^{4}$ & mesic & e & 0.72 & 0.04 & 0.02 & 0.00 & 0.00 & 0.78 & 6.04 & 6.20 \\
\hline $12-13$ & 59.786 & -112.601 & $105^{4}$ & hygric & $f$ & 0.04 & 0.03 & 0.02 & 0.00 & 0.00 & 0.09 & 4.37 & 4.20 \\
\hline $14-14$ & 60.034 & -113.116 & 2 & subhygric & $g$ & 0.55 & 0.06 & 0.06 & 0.00 & 0.40 & 1.07 & 0.00 & 1.07 \\
\hline $13-25$ & 60.139 & -113.660 & 9 & subhygric & $g$ & 0.14 & 0.09 & 0.07 & 0.00 & 0.00 & 0.30 & 0.00 & 0.30 \\
\hline $14-13$ & 60.035 & -113.105 & 90 & subhygric & g & 0.19 & 0.04 & 0.08 & 0.00 & 0.28 & 0.59 & 1.06 & 1.91 \\
\hline $13-03$ & 59.528 & -114.559 & $113^{5}$ & subhygric & $g$ & 0.00 & 0.04 & 0.04 & 0.00 & 0.19 & 0.26 & 4.85 & 5.30 \\
\hline
\end{tabular}

Page 1 
S1

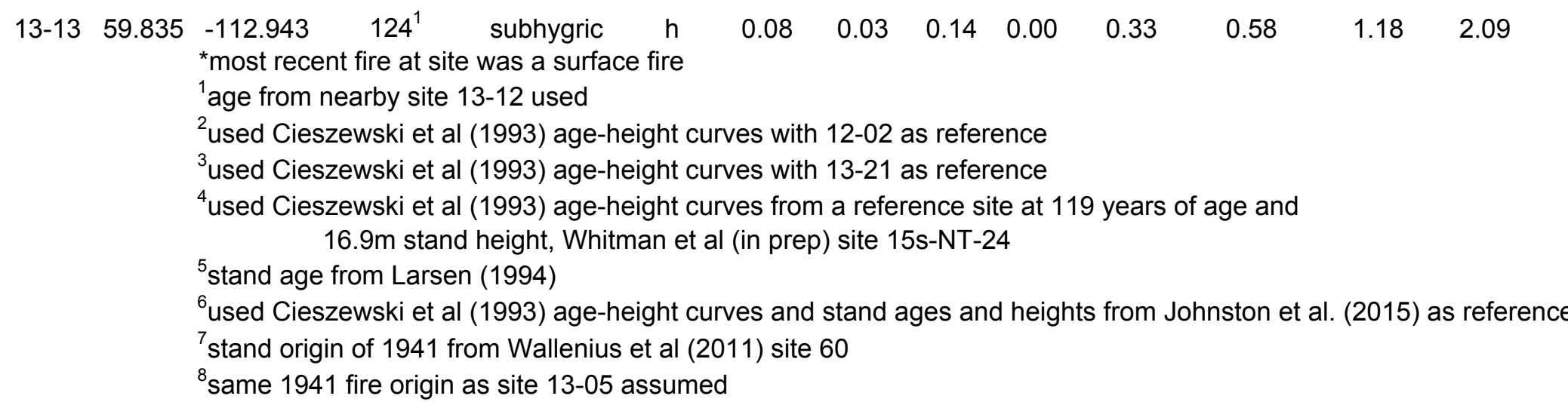




\section{Canadian Journal of Forest Research}

S1

Page 4

https://mc06.manuscriptcentral.com/cjfr-pubs 


\section{Canadian Journal of Forest Research}

Page 42 of 56

S1

Page 6

https://mc06.manuscriptcentral.com/cjfr-pubs 
S1

SD_live_ha SmTreeAllLiveDensity_ha

$\begin{array}{rr}379 & 236 \\ 0 & 0 \\ 0 & 2122 \\ 0 & 154203 \\ 6127 & 7427 \\ 3427 & 1627 \\ 2603 & 0 \\ 2924 & 354 \\ 850 & 1061 \\ 0 & 37136 \\ 1989 & 0 \\ 0 & 0 \\ 440 & 0 \\ 3435 & 0 \\ 2253 & 884 \\ 901 & 236 \\ 590 & 6897 \\ 569 & 1533 \\ 0 & 0 \\ 98 & 3890 \\ 4466 & 472 \\ 1404 & 0 \\ 1120 & 0 \\ 2384 & 0 \\ 607 & 2358 \\ 547 & 1650 \\ 1498 & 1297 \\ 1439 & 619 \\ 316 & 67906 \\ 0 & 12909 \\ 4329 & 21928 \\ 6631 & 17330\end{array}$

Page 7

https://mc06.manuscriptcentral.com/cjfr-pubs 
S1

SD_live_ha SmTreeAllLiveDensity_ha

0

0

0

0

225

1578

1249

248

4539

727

0

0

0

0

0

0

0

29

0

0

0

0

0

0
354

0
9726
13086
10257
5836

4598
0
16033
1650
0
0
0
0
0
0
0
0
472
1650
0
0
0
0
2829
0
0
0

Page 8

https://mc06.manuscriptcentral.com/cjfr-pubs 
S1

$\begin{array}{rr}0 & 0 \\ 0 & 0 \\ 2293 & 6013\end{array}$

Page 9

https://mc06.manuscriptcentral.com/cjfr-pubs 
SmTreeConiLiveDensity_ha SmTreeLiveBA_m2_ha LrgTreeLiveBA_m2_ha TotalLiveBA ConiBA LiveLoreyH LiveLoreyCBH LiveConifer_CBD

$\begin{array}{rr}236 & 0 \\ 0 & 0 \\ 2122 & 0.2 \\ 154203 & 10.7 \\ 7427 & 2.2 \\ 849 & 0.3 \\ 0 & 0 \\ 118 & 0 \\ 1061 & 0.1 \\ 26526 & 2.6 \\ 0 & 0 \\ 0 & 0 \\ 0 & 0 \\ 0 & 0 \\ 884 & 0.5 \\ 236 & 0 \\ 2476 & 1.7 \\ 1533 & 0.2 \\ 0 & 0 \\ 1415 & 0.1 \\ 236 & 0.1 \\ 0 & 0 \\ 0 & 0 \\ 0 & 0 \\ 354 & 0.4 \\ 472 & 0.4 \\ 707 & 0.1 \\ 619 & 0 \\ 67906 & 7.1 \\ 8665 & 0.2 \\ 21221 & 4.6 \\ 14147 & 4.2\end{array}$

$\begin{array}{rrrr}14.4 & 14.4 & 14.4 & 24.38 \\ 0 & 0 & 0 & \\ 0 & 0.2 & 0 & \\ 0 & 10.7 & 0 & \\ 10.1 & 12.3 & 12.3 & 6.49 \\ 31.1 & 31.4 & 31 & 13.31 \\ 14.9 & 14.9 & 14.9 & 12.57 \\ 19.6 & 19.6 & 19.6 & 13.62 \\ 28.1 & 28.3 & 28.3 & 18.58 \\ 0 & 2.6 & 0 & \\ 20.1 & 20.1 & 20.1 & 14.36 \\ 0 & 0 & 0 & \\ 8.8 & 8.8 & 5.6 & 19.86 \\ 15.3 & 15.3 & 0 & 10.75 \\ 27.3 & 27.8 & 15.8 & 13.02 \\ 13.5 & 13.5 & 13.5 & 16.55 \\ 17.2 & 18.8 & 13.1 & 20.97 \\ 12.9 & 13.1 & 13.1 & 18.37 \\ 0 & 0 & 0 & \\ 0.1 & 0.2 & 0 & 20.97 \\ 22.1 & 22.2 & 14.3 & 10.36 \\ 24.9 & 24.9 & 0 & 18 \\ 17 & 17 & 5.6 & 17.63 \\ 20.9 & 20.9 & 0 & 12.35 \\ 19.4 & 19.8 & 1 & 23.43 \\ 21.7 & 22.1 & 18.6 & 24.89 \\ 54.4 & 54.5 & 48.9 & 20.89 \\ 35.4 & 35.4 & 33.3 & 16.8 \\ 0 & 7.1 & 6.2 & 3.36 \\ 0 & 0.2 & 0 & \\ 7.4 & 12 & 11.8 & 5.21 \\ 23.1 & 27.2 & 27.2 & 6.58\end{array}$

18.76

0.17

0
2

0.7
2.2

0.3
0

0

2.6

0

0

0.5
0

1.7

0

0.1

0

0

0.4

0.4

0

0.2

4.6
4.2

23.1

6.58

\subsection{5}

5.63

6.68

0.47

0.27

6.13

10.12

0.2

0.21

6.59

0.18

13.32

6.12

7.74

8.94

13.02

9.92

0.06

0

0.28

0.12

0.1

0.1

16.71

5.49

13.27

10.95

8.19

15.18

11.52

8.71

9.49

0.05

0
0.2

0.2
0

0.06

0

0.01

0.14

0.44

0.56

2.17

0.34

Page 10 
22282 5.8

S1

8

13.7

13.7

6.85

2.23

0.26

SmTreeConiLiveDensity_ha SmTreeLiveBA_m2_ha LrgTreeLiveBA_m2_ha TotalLiveBA ConiBA LiveLoreyH LiveLoreyCBH LiveConifer_CBD

\begin{tabular}{|c|c|c|c|c|c|c|c|}
\hline 354 & 0.1 & 0 & 0.1 & 0 & & & \\
\hline 0 & 0 & 0 & 0 & 0 & & & \\
\hline 9726 & 0 & 0 & 0 & 0 & & & \\
\hline 12025 & 0.2 & 0 & 0.2 & 0 & & & \\
\hline 10257 & 1.8 & 0.2 & 2 & 2 & 3.65 & 0.07 & 0.01 \\
\hline 5836 & 1.4 & 2.4 & 3.8 & 3.8 & 3.87 & 1.29 & 0.23 \\
\hline 3183 & 1 & 1.6 & 2.6 & 2.3 & 4.17 & 0.63 & 0.06 \\
\hline 0 & 0 & 0.6 & 0.6 & 0.6 & 4.82 & 0.57 & 0.03 \\
\hline 8488 & 1.5 & 12.4 & 13.9 & 13.1 & 6.75 & 5.06 & 1.12 \\
\hline 1650 & 0.3 & 2.8 & 3.1 & 3.1 & 6.14 & 1.28 & 0.11 \\
\hline 0 & 0 & 0 & 0 & 0 & & & \\
\hline 0 & 0 & 0 & 0 & 0 & & & \\
\hline 0 & 0 & 0 & 0 & 0 & & & \\
\hline 0 & 0 & 0 & 0 & 0 & & & \\
\hline 0 & 0 & 0 & 0 & 0 & & & \\
\hline 0 & 0 & 0 & 0 & 0 & & & \\
\hline 0 & 0 & 0 & 0 & 0 & & & \\
\hline 0 & 0 & 0 & 0 & 0 & & & \\
\hline 472 & 0.1 & 0 & 0.1 & 0.1 & 3.07 & 0.74 & 0 \\
\hline 1061 & 0.5 & 0 & 0.5 & 0 & & & \\
\hline 0 & 0 & 0 & 0 & 0 & & & \\
\hline 0 & 0 & 0 & 0 & 0 & & & \\
\hline 0 & 0 & 0 & 0 & 0 & & & \\
\hline 0 & 0 & 0 & 0 & 0 & & & \\
\hline 2829 & 0.6 & 0 & 0.6 & 0 & & & \\
\hline 0 & 0 & 0 & 0 & 0 & & & \\
\hline 0 & 0 & 0 & 0 & 0 & & & \\
\hline 0 & 0 & 0 & 0 & 0 & & & \\
\hline
\end{tabular}

Page 11

https://mc06.manuscriptcentral.com/cjfr-pubs 
0

0
6013
0

0
0.8
S1

$\begin{array}{rrrr}0 & 0 & 0 & \\ 0 & 0 & 0 & \\ 11 & 11.8 & 11.8 & 9.64\end{array}$

9.64

3.16

0.25

Page 12

https://mc06.manuscriptcentral.com/cjfr-pubs 


\begin{tabular}{|c|c|c|c|c|c|c|}
\hline & & & $\mathrm{S} 2$ & & & \\
\hline Site & Lat & Long & $\begin{array}{c}\text { Time Since } \\
\text { Fire }\end{array}$ & Vegetation Class & Drainage & Ecosite \\
\hline $13-19$ & 59.973 & -112.472 & $1^{*}$ & Treed peatland & subhydric & $\mathrm{i}$ \\
\hline $15-02$ & 59.780 & -112.350 & 1 & Treed peatland & subhydric & $\mathrm{i}$ \\
\hline $13-07$ & 59.383 & -113.367 & 6 & Open peatland & subhydric & $\mathrm{i}$ \\
\hline $13-08$ & 59.382 & -113.368 & 6 & Treed peatland & hygric & $\mathrm{i}$ \\
\hline $14-17$ & 60.195 & -113.751 & 10 & Treed peatland & subhydric & $\mathrm{i}$ \\
\hline $13-09$ & 59.382 & -113.374 & $83^{6}$ & Shrub peatland & subhydric & $\mathrm{i}$ \\
\hline $14-03$ & 60.138 & -113.657 & 86 & Treed peatland & subhydric & $\mathrm{i}$ \\
\hline $15-13$ & 60.270 & -113.973 & 1 & Treed peatland & subhydric & $\mathrm{j}$ \\
\hline $14-06$ & 60.048 & -112.823 & 31 & ruce dominated mix & subhydric & $j$ \\
\hline $13-20$ & 59.945 & -112.491 & $32^{*}$ & Treed peatland & hygric & $j$ \\
\hline $14-20$ & 60.195 & -113.753 & 69 & Treed peatland & subhydric & j \\
\hline $13-04$ & 59.527 & -114.561 & $113^{5}$ & Treed peatland & hygric & $j$ \\
\hline $13-18$ & 59.975 & -112.471 & 1 & Sedge marsh & hydric & $\mathrm{k}$ \\
\hline $12-10$ & 58.607 & -111.691 & 2 & Wet meadow & subhydric & $\mathrm{k}$ \\
\hline $12-06$ & 58.627 & -111.679 & 8 & Semi-open prairie & subhydric & $\mathrm{k}$ \\
\hline $12-07$ & 58.628 & -111.677 & 8 & Semi-open prairie & subhydric & $\mathrm{k}$ \\
\hline $12-08$ & 58.630 & -111.672 & 8 & Sedge marsh & hydric & $\mathrm{k}$ \\
\hline $12-09$ & 58.630 & -111.673 & 8 & Wet meadow & subhydric & $\mathrm{k}$ \\
\hline $13-14$ & 59.028 & -111.874 & 14 & nally submerged $\mathrm{m}$ & hydric & $\mathrm{k}$ \\
\hline $13-06$ & 59.436 & -112.362 & 32 & Shrub peatland & subhydric & $\mathrm{k}$ \\
\hline $13-22$ & 59.280 & -112.473 & 32 & Shrub peatland & subhydric & $\mathrm{k}$ \\
\hline $12-04$ & 59.515 & -111.459 & 64 & nally submerged $\mathrm{m}$ & subhydric & $\mathrm{k}$ \\
\hline $13-24$ & 59.689 & -111.530 & 72 & Sedge marsh & hydric & $\mathrm{k}$ \\
\hline $12-12$ & 59.786 & -112.602 & $105^{4}$ & Rich fen & subhydric & $\mathrm{k}$ \\
\hline $13-11$ & 59.828 & -112.864 & $124^{1}$ & Shrub peatland & hydric & $\mathrm{k}$ \\
\hline $13-27$ & 58.841 & -111.991 & $155^{4}$ & Semi-open prairie & subhydric & $\mathrm{k}$ \\
\hline $13-28$ & 58.858 & -111.992 & $155^{4}$ & Nillow-alder thickets & subhydric & $\mathrm{k}$ \\
\hline $13-30$ & 58.851 & -111.992 & $155^{4}$ & Nillow-alder thickets & hydric & $\mathrm{k}$ \\
\hline $14-18$ & 58.839 & -111.978 & 1 & Wet meadow & hydric & I \\
\hline $14-01$ & 59.812 & -111.967 & 61 & It flats saline meadı & subhydric & I \\
\hline $13-05$ & 59.961 & -112.363 & $72^{7}$ & It flats saline meadı & subhydric & I \\
\hline $14-09$ & 59.551 & -111.468 & $73^{8}$ & Wet meadow & hydric & I \\
\hline $14-02$ & 59.359 & -113.717 & $250^{4}$ & Treed peatland & subhydric & I \\
\hline
\end{tabular}

Page 13 


\begin{tabular}{|c|c|c|c|c|c|c|}
\hline \multirow[b]{2}{*}{ Litter } & \multicolumn{6}{|c|}{$\mathrm{S} 2$} \\
\hline & Wood & Live & Shrub & $\begin{array}{l}\text { Under } \\
\mathrm{kg} \mathrm{m}-2\end{array}$ & $\Sigma$ Surface & $\Sigma$ Crown \\
\hline 0.08 & 0.00 & 0.03 & 0.00 & 0.25 & 0.36 & 0.00 \\
\hline 0.08 & 0.04 & 0.08 & 0.00 & 0.00 & 0.20 & 0.00 \\
\hline 0.07 & 0.00 & 0.10 & 0.00 & 0.00 & 0.17 & 0.00 \\
\hline 0.20 & 0.05 & 0.19 & 0.00 & 0.08 & 0.52 & 0.00 \\
\hline & 0.00 & & 0.00 & 0.01 & 0.01 & 0.00 \\
\hline 0.11 & 0.00 & 0.52 & 0.00 & 0.12 & 0.75 & 0.04 \\
\hline 0.56 & 0.03 & 0.05 & 0.00 & 0.10 & 0.74 & 0.60 \\
\hline 0.04 & 0.01 & 0.01 & 0.00 & 0.00 & 0.05 & 0.00 \\
\hline 0.10 & 0.00 & 0.02 & 0.06 & 0.05 & 0.22 & 0.24 \\
\hline 0.13 & 0.00 & 0.29 & 0.01 & 0.00 & 0.43 & 0.11 \\
\hline 0.06 & 0.00 & 0.09 & 0.00 & 0.05 & 0.20 & 2.00 \\
\hline 0.06 & 0.04 & 0.10 & 0.00 & 0.02 & 0.22 & 0.55 \\
\hline 0.00 & 0.00 & 0.25 & 0.01 & 0.00 & 0.26 & 0.00 \\
\hline 0.29 & 0.00 & 0.43 & 0.00 & 0.00 & 0.72 & 0.00 \\
\hline 0.63 & 0.00 & 0.11 & 0.00 & 0.00 & 0.74 & 0.00 \\
\hline 0.63 & 0.00 & 0.10 & 0.00 & 0.00 & 0.73 & 0.00 \\
\hline 0.44 & 0.00 & 0.02 & 0.00 & 0.00 & 0.46 & 0.00 \\
\hline 0.36 & 0.00 & 0.20 & 0.00 & 0.00 & 0.56 & 0.00 \\
\hline 0.08 & 0.00 & 0.25 & 0.00 & 0.00 & 0.33 & 0.00 \\
\hline 0.14 & 0.00 & 0.03 & 0.00 & 0.00 & 0.17 & 0.00 \\
\hline 0.24 & 0.00 & 0.08 & 0.23 & 0.01 & 0.55 & 0.00 \\
\hline 0.22 & 0.00 & 0.15 & 0.00 & 0.02 & 0.39 & 0.00 \\
\hline 0.84 & 0.00 & 0.35 & 0.10 & 0.00 & 1.29 & 0.00 \\
\hline 0.07 & 0.00 & 0.00 & 0.00 & 0.00 & 0.07 & 0.00 \\
\hline 0.22 & 0.03 & 0.30 & 0.16 & 0.00 & 0.71 & 0.00 \\
\hline 0.49 & 0.00 & 0.23 & 0.00 & 0.00 & 0.72 & 0.00 \\
\hline 0.32 & 0.06 & 0.04 & 5.87 & 0.05 & 0.47 & 0.00 \\
\hline 0.36 & 0.00 & 0.17 & 2.06 & 0.00 & 0.53 & 0.00 \\
\hline 0.06 & 0.00 & 0.47 & 0.00 & 0.00 & 0.53 & 0.00 \\
\hline 0.09 & 0.00 & 0.10 & 0.00 & 0.00 & 0.19 & 0.00 \\
\hline 0.40 & 0.00 & 0.13 & 0.00 & 0.00 & 0.53 & 0.00 \\
\hline 0.17 & 0.01 & 0.09 & 0.00 & 0.00 & 0.27 & 0.00 \\
\hline 0.21 & 0.05 & 0.16 & 0.00 & 0.05 & 0.47 & 1.61 \\
\hline
\end{tabular}

Page 14 


\begin{tabular}{l}
$\boldsymbol{}$ \\
\hline Fuel \\
\\
0.36 \\
0.20 \\
0.17 \\
0.52 \\
0.02 \\
0.90 \\
1.44 \\
0.05 \\
0.54 \\
0.56 \\
2.13 \\
0.79 \\
0.26 \\
0.72 \\
0.74 \\
0.73 \\
0.46 \\
0.56 \\
0.33 \\
0.17 \\
0.79 \\
0.39 \\
1.39 \\
0.07 \\
0.86 \\
0.72 \\
6.39 \\
2.59 \\
0.53 \\
0.19 \\
0.53 \\
0.27 \\
2.12 \\
\hline
\end{tabular}

S2

0.36

0.20

0.17

0.52

0.02

0.90

0.54

0.56

0.79

0.26

0.72

.74

.73

0.56

0.17

0.79

39

.07

0.72

6.39

.59

.53

19

.53

2.12

Page 15

https://mc06.manuscriptcentral.com/cjfr-pubs 


\begin{tabular}{|c|c|c|c|c|c|c|}
\hline Site & $\begin{array}{c}\text { CWD }<7 \mathrm{~cm} \\
\left(\mathrm{~kg} \mathrm{~m}^{-2}\right)\end{array}$ & $\begin{array}{l}\text { CWDTotal } \\
\mathrm{kg} \mathrm{m}^{-2}\end{array}$ & $\begin{array}{c}\text { Stems }>7 \\
\mathrm{~cm} \\
\left(\text { stems ha }^{-1}\right)\end{array}$ & $\begin{array}{c}\text { Stems }<7 \\
\mathrm{~cm} \\
\left(\text { stems } \mathrm{ha}^{-1}\right)\end{array}$ & $\begin{array}{l}\text { Total Live } \\
\text { Basal Area } \\
\left(\mathrm{m}^{2} \mathrm{ha}^{-1}\right)\end{array}$ & $\begin{array}{c}\text { Conifer Live } \\
\text { Basal Area } \\
\left(\mathrm{m}^{2} \mathrm{ha}^{-1}\right)\end{array}$ \\
\hline $14-07$ & 0.09 & 0.09 & 379 & 236 & 14.4 & 14.4 \\
\hline $14-08$ & 0.13 & 0.13 & 0 & 0 & 0 & 0 \\
\hline $13-01$ & 1.17 & 1.17 & 0 & 2122 & 0.2 & 0 \\
\hline $12-03$ & 0.08 & 0.08 & 6127 & 7427 & 12.3 & 12.3 \\
\hline $12-05$ & 0.05 & 0.05 & 3427 & 1627 & 31.4 & 31 \\
\hline $13-16$ & 1.58 & 5.24 & 0 & 154203 & 10.7 & 0 \\
\hline $13-02$ & 0.45 & 0.45 & 2603 & 0 & 14.9 & 14.9 \\
\hline $13-10$ & 0.66 & 0.66 & 2924 & 354 & 19.6 & 19.6 \\
\hline $12-01$ & 0.31 & 1.29 & 850 & 1061 & 28.3 & 28.3 \\
\hline $14-10$ & 0.6 & 0.6 & 0 & 37136 & 2.6 & 0 \\
\hline $14-19$ & 0.91 & 0.91 & 1989 & 0 & 20.1 & 20.1 \\
\hline $13-26$ & 0.26 & 0.26 & 0 & 0 & 0 & 0 \\
\hline $14-15$ & 0.37 & 1.16 & 440 & 0 & 8.8 & 5.6 \\
\hline $13-23$ & 0.59 & 0.88 & 3435 & 0 & 15.3 & 0 \\
\hline $12-11$ & 0.23 & 0.23 & 2253 & 884 & 27.8 & 15.8 \\
\hline $14-12$ & 0.52 & 0.52 & 901 & 236 & 13.5 & 13.5 \\
\hline $14-16$ & 0.17 & 0.29 & 590 & 6897 & 18.8 & 13.1 \\
\hline $14-11$ & 0.16 & 0.16 & 569 & 1533 & 13.1 & 13.1 \\
\hline $13-17$ & 0.89 & 1.97 & 0 & 0 & 0 & 0 \\
\hline $14-04$ & 0.36 & 2.36 & 98 & 3890 & 0.2 & 0 \\
\hline $12-02$ & 0.68 & 10.03 & 4466 & 472 & 22.2 & 14.3 \\
\hline $14-21$ & 1.01 & 1.14 & 1404 & 0 & 24.9 & 0 \\
\hline $13-21$ & 0.63 & 0.73 & 1120 & 0 & 17 & 5.6 \\
\hline $13-12$ & 0.51 & 0.51 & 2384 & 0 & 20.9 & 0 \\
\hline $13-15$ & 0.02 & 3.08 & 607 & 2358 & 19.8 & 1 \\
\hline $14-05$ & 0.37 & 1.51 & 547 & 1650 & 22.1 & 18.6 \\
\hline $13-29$ & 0.77 & 2.59 & 1498 & 1297 & 54.5 & 48.9 \\
\hline $12-13$ & 0.16 & 1.92 & 1439 & 619 & 35.4 & 33.3 \\
\hline $14-14$ & 1.28 & 1.4 & 316 & 67906 & 7.1 & 6.2 \\
\hline $13-25$ & 1.81 & 4.43 & 0 & 12909 & 0.2 & 0 \\
\hline $14-13$ & 1.01 & 1.11 & 4329 & 21928 & 12 & 11.8 \\
\hline $13-03$ & 0.18 & 0.18 & 6631 & 17330 & 27.2 & 27.2 \\
\hline $13-13$ & 0.11 & 0.11 & 2572 & 23696 & 13.7 & 13.7 \\
\hline
\end{tabular}

Page 16 


\begin{tabular}{|c|c|c|}
\hline $\begin{array}{l}\text { Live Lorey } \\
\text { Height } \\
(\mathrm{m}) \\
24.38\end{array}$ & $\begin{array}{l}\text { Live Lorey } \\
\text { Crown Base } \\
\text { Height } \\
(\mathrm{m}) \\
18.76\end{array}$ & $\begin{array}{c}\text { Live Conifer } \\
\text { Crown Bulk } \\
\text { Density } \\
\left(\mathrm{kg} \mathrm{m}^{-3}\right) \\
0.17\end{array}$ \\
\hline 6.49 & 4.45 & 0.47 \\
\hline 13.31 & 5.63 & 0.27 \\
\hline 12.57 & 6.68 & 0.2 \\
\hline 13.62 & 6.13 & 0.2 \\
\hline 18.58 & 10.12 & 0.21 \\
\hline 14.36 & 6.59 & 0.18 \\
\hline 19.86 & 13.32 & 0.06 \\
\hline 10.75 & 6.12 & 0 \\
\hline 13.02 & 7.74 & 0.28 \\
\hline 16.55 & 8.94 & 0.12 \\
\hline 20.97 & 13.02 & 0.1 \\
\hline 18.37 & 9.92 & 0.1 \\
\hline 20.97 & 16.71 & 0 \\
\hline 10.36 & 5.49 & 0.2 \\
\hline 18 & 13.27 & 0 \\
\hline 17.63 & 10.95 & 0.06 \\
\hline 12.35 & 8.19 & 0 \\
\hline 23.43 & 15.18 & 0.01 \\
\hline 24.89 & 11.52 & 0.14 \\
\hline 20.89 & 8.71 & 0.44 \\
\hline 16.8 & 9.49 & 0.56 \\
\hline 3.36 & 0.05 & 0 \\
\hline 5.21 & 2.17 & 0.34 \\
\hline 6.58 & 2.15 & 1.1 \\
\hline 6.85 & 2.23 & 0.26 \\
\hline
\end{tabular}

Page 17

https://mc06.manuscriptcentral.com/cjfr-pubs 


\begin{tabular}{|c|c|c|c|c|c|c|}
\hline \multirow[b]{2}{*}{ Site } & \multicolumn{6}{|c|}{$\mathrm{S} 4$} \\
\hline & $\begin{array}{c}\text { CWD }<7 \mathrm{~cm} \\
\left(\mathrm{~kg} \mathrm{~m}^{-2}\right)\end{array}$ & $\begin{array}{l}\text { CWDTotal } \\
\mathrm{kg} \mathrm{m}^{-2}\end{array}$ & $\begin{array}{c}\text { Stems }>7 \\
\mathrm{~cm} \\
\left(\text { stems } \mathrm{ha}^{-1}\right)\end{array}$ & $\begin{array}{c}\text { Stems }<7 \\
\mathrm{~cm} \\
\left(\text { stems } \mathrm{ha}^{-1}\right)\end{array}$ & $\begin{array}{l}\text { Total Live } \\
\text { Basal Area } \\
\left(\mathrm{m}^{2} \mathrm{ha}^{-1}\right)\end{array}$ & $\begin{array}{c}\text { Conifer Live } \\
\text { Basal Area } \\
\left(\mathrm{m}^{2} \mathrm{ha}^{-1}\right)\end{array}$ \\
\hline $13-19$ & 0.04 & 0.04 & 0 & 354 & 0.1 & 0 \\
\hline $15-02$ & 0.065 & 0.065 & & & & \\
\hline $13-07$ & 0 & 0 & 0 & 0 & 0 & 0 \\
\hline $13-08$ & 0.32 & 0.32 & 0 & 9726 & 0 & 0 \\
\hline $14-17$ & 0.13 & 0.13 & 0 & 13086 & 0.2 & 0 \\
\hline $13-09$ & 0 & 0 & 225 & 10257 & 2 & 2 \\
\hline $14-03$ & 0.12 & 0.12 & 1578 & 5836 & 3.8 & 3.8 \\
\hline $15-13$ & 0.03 & 0.03 & & & & \\
\hline $14-06$ & 0.19 & 0.19 & 1249 & 4598 & 2.6 & 2.3 \\
\hline $13-20$ & 0.07 & 0.07 & 248 & 0 & 0.6 & 0.6 \\
\hline $14-20$ & 0.11 & 0.39 & 4539 & 16033 & 13.9 & 13.1 \\
\hline $13-04$ & 0.07 & 0.07 & 727 & 1650 & 3.1 & 3.1 \\
\hline $13-18$ & 0 & 0 & 0 & 0 & 0 & 0 \\
\hline $12-10$ & 0 & 0 & 0 & 0 & 0 & 0 \\
\hline $12-06$ & 0 & 0 & 0 & 0 & 0 & 0 \\
\hline $12-07$ & 0 & 0 & 0 & 0 & 0 & 0 \\
\hline $12-08$ & 0 & 0 & 0 & 0 & 0 & 0 \\
\hline $12-09$ & 0 & 0 & 0 & 0 & 0 & 0 \\
\hline $13-14$ & 0 & 0 & 0 & 0 & 0 & 0 \\
\hline $13-06$ & 0 & 0 & 0 & 0 & 0 & 0 \\
\hline $13-22$ & 0 & 0 & 29 & 472 & 0.1 & 0.1 \\
\hline $12-04$ & 0 & 0 & 0 & 1650 & 0.5 & 0 \\
\hline $13-24$ & 0 & 0 & 0 & 0 & 0 & 0 \\
\hline $12-12$ & 0 & 0 & 0 & 0 & 0 & 0 \\
\hline $13-11$ & 0.21 & 0.21 & 0 & 0 & 0 & 0 \\
\hline $13-27$ & 0 & 0 & 0 & 0 & 0 & 0 \\
\hline $13-28$ & 0.87 & 0.87 & 0 & 2829 & 0.6 & 0 \\
\hline $13-30$ & 0 & 0 & 0 & 0 & 0 & 0 \\
\hline $14-18$ & 0.13 & 0.13 & 0 & 0 & 0 & 0 \\
\hline $14-01$ & 0 & 0 & 0 & 0 & 0 & 0 \\
\hline $13-05$ & 0 & 0 & 0 & 0 & 0 & 0 \\
\hline $14-09$ & 0.13 & 0.13 & 0 & 0 & 0 & 0 \\
\hline $14-02$ & 0.11 & 0.11 & 2293 & 6013 & 11.8 & 11.8 \\
\hline
\end{tabular}

Page 18 


$\begin{array}{ccc}\begin{array}{c}\text { Live Lorey } \\ \text { Height } \\ (\mathrm{m})\end{array} & \begin{array}{c}\text { Live Lorey } \\ \text { Crown Base } \\ \text { Height } \\ (\mathrm{m})\end{array} & \begin{array}{c}\text { Live Con } \\ \text { Crown B } \\ \text { Densit } \\ \left(\mathrm{kg} \mathrm{m}^{-3}\right)\end{array} \\ & & \\ & & \\ & & \\ 3.65 & 0.07 & 0.01 \\ 3.87 & 1.29 & 0.23 \\ 4.17 & 0.63 & 0.06 \\ 4.82 & 0.57 & 0.03 \\ 6.75 & 5.06 & 1.12 \\ 6.14 & 1.28 & 0.11\end{array}$

S4

$\begin{array}{lll}3.07 & 0.74 & 0\end{array}$

$\begin{array}{lll}9.64 & 3.16 & 0.25\end{array}$

Page 19

https://mc06.manuscriptcentral.com/cjfr-pubs 


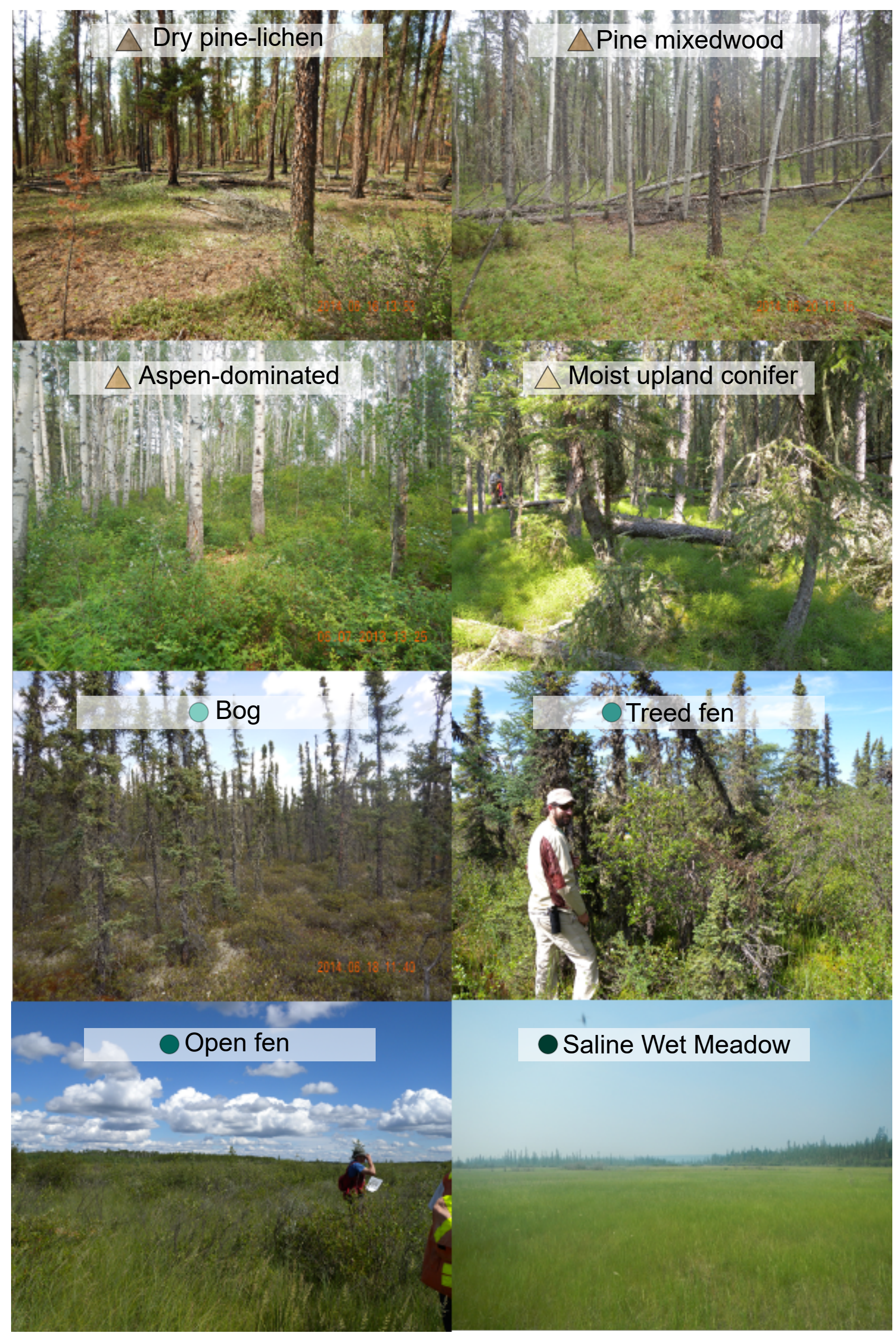

